Supporting Information

\title{
Decomposition of Vanadium(V) Alkylidenes Relevant to Olefin Metathesis
}

\author{
authored by
}

Wesley S. Farrell, ${ }^{*, \dagger}$ Christine Greene, ${ }^{\ddagger}$ Pokhraj Ghosh, ${ }^{\ddagger}$ Timothy H. Warren, ${ }^{\ddagger}$ and Peter Y. Zavalij ${ }^{\S}$

${ }^{\dagger}$ Chemistry Department, United States Naval Academy, 572M Holloway Road, Annapolis, Maryland 21402, United States

Department of Chemistry, Georgetown University, Box 571227-1227, Washington, DC 20057, United States

${ }^{\S}$ Department of Chemistry and Biochemistry, University of Maryland, College Park, Maryland 20742, United States

*E-mail: wfarrell@usna.edu

\section{Table of Contents}

1. NMR Spectra $\quad$ S2

2. EPR Spectra $\quad$ S20

3. GC-FID Data $\quad$ S21

4. Computational Data and Figures $\quad$ S21

5. Crystallographic Information $\quad$ S42

6. References $\quad$ S46 


\section{NMR SPECTRA}

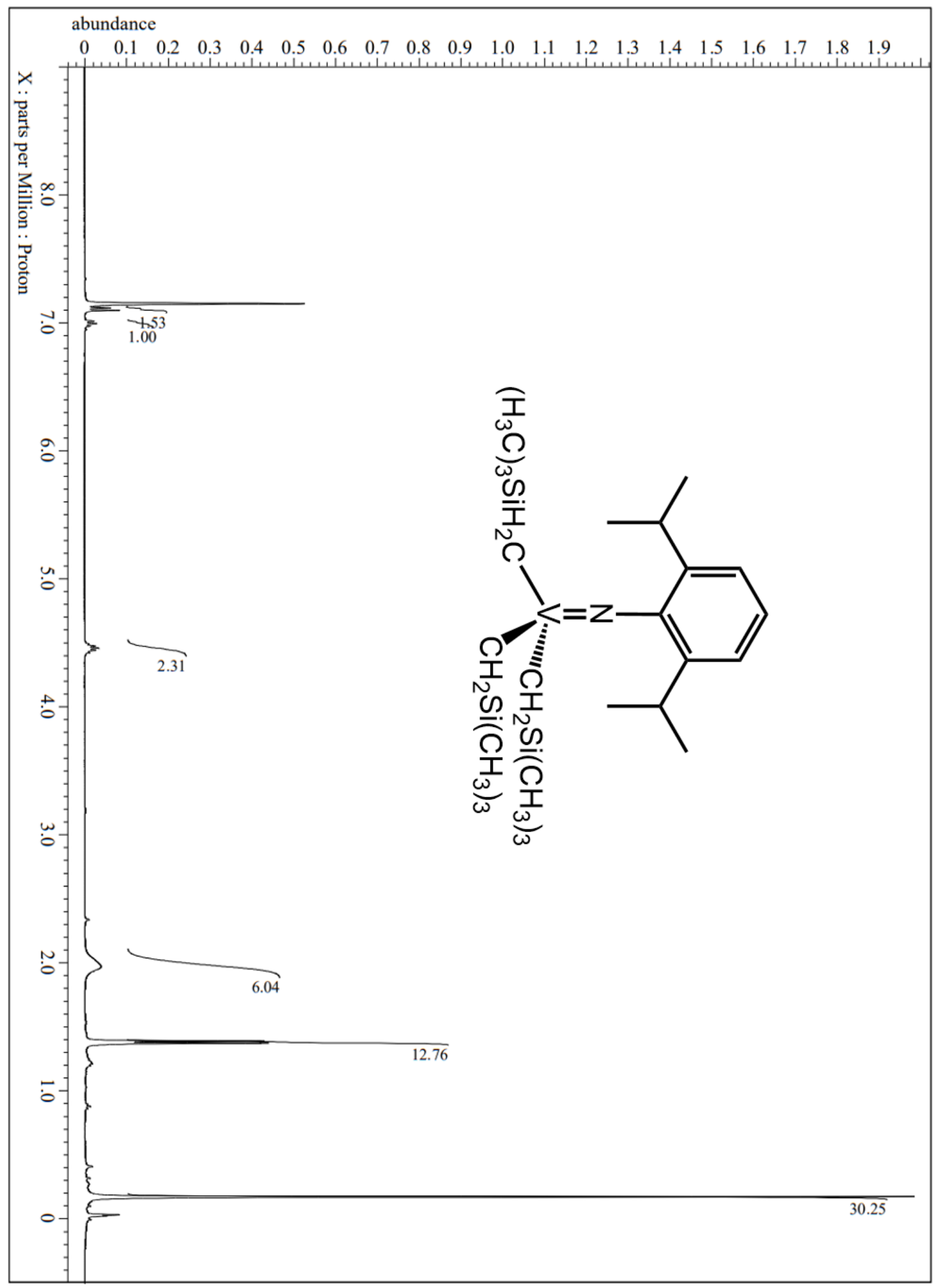

Figure S1. ${ }^{1} \mathrm{H}\left(400 \mathrm{MHz}\right.$, benzene- $\left.d_{6}, 25^{\circ} \mathrm{C}\right) \mathrm{NMR}$ of compound 17. 


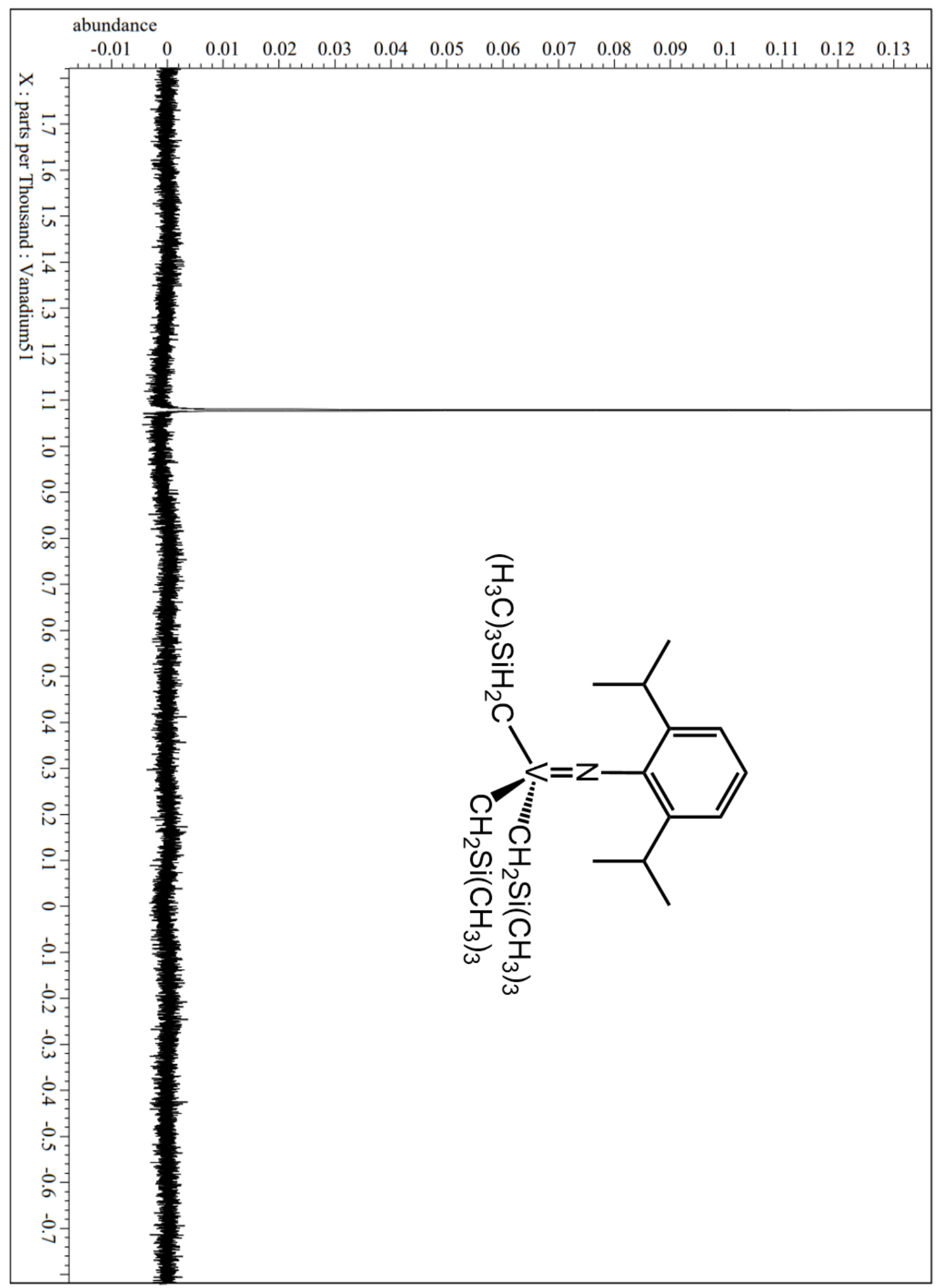

Figure S2. ${ }^{51} \mathrm{~V}$ (105 MHz, benzene- $\left.d_{6}, 25^{\circ} \mathrm{C}\right) \mathrm{NMR}$ of compound 17. 


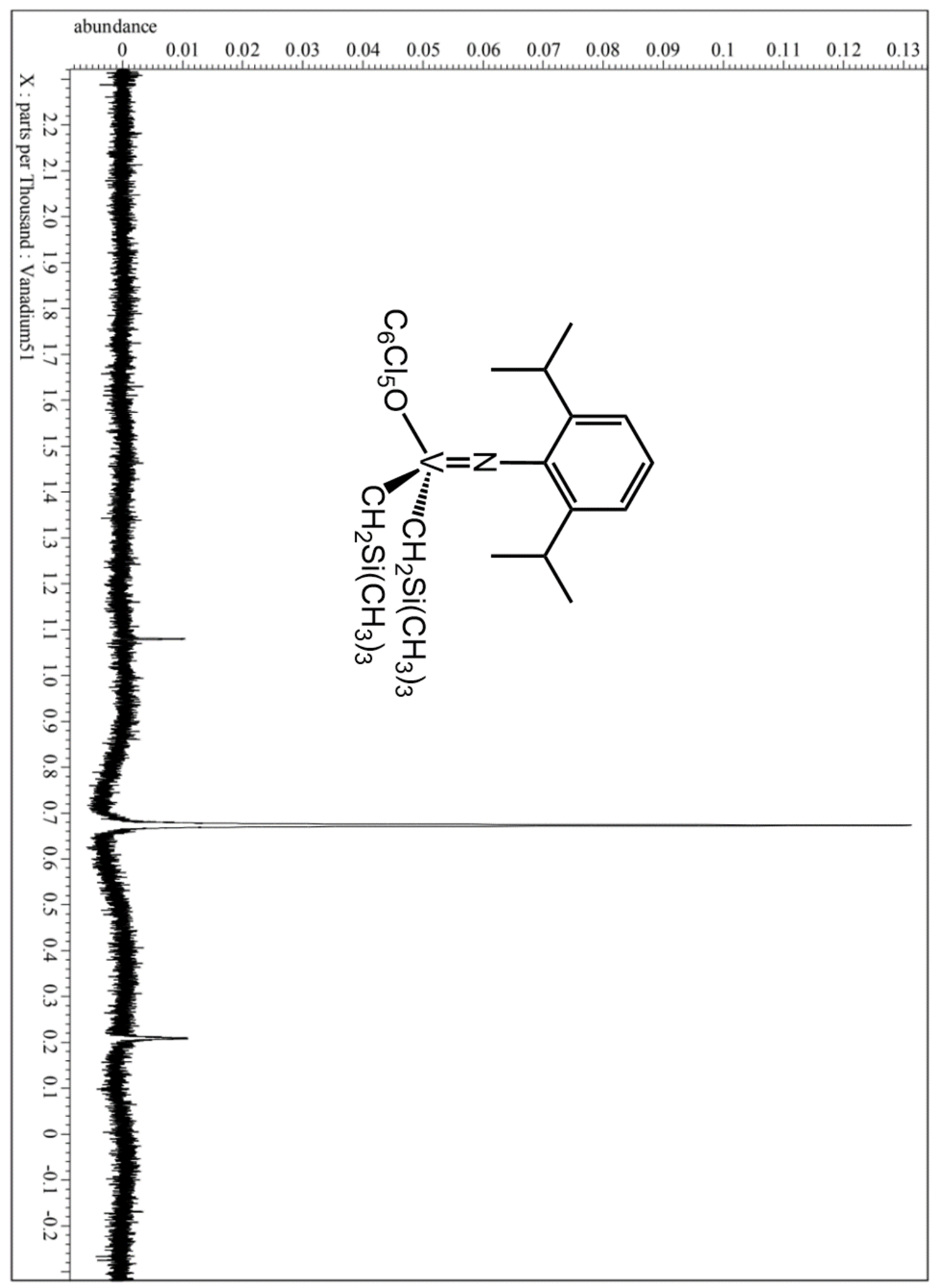

Figure S3. ${ }^{51} \mathrm{~V}\left(105 \mathrm{MHz}\right.$, benzene- $\left.d_{6}, 25^{\circ} \mathrm{C}\right) \mathrm{NMR}$ of compound $\mathbf{1 8}$. 


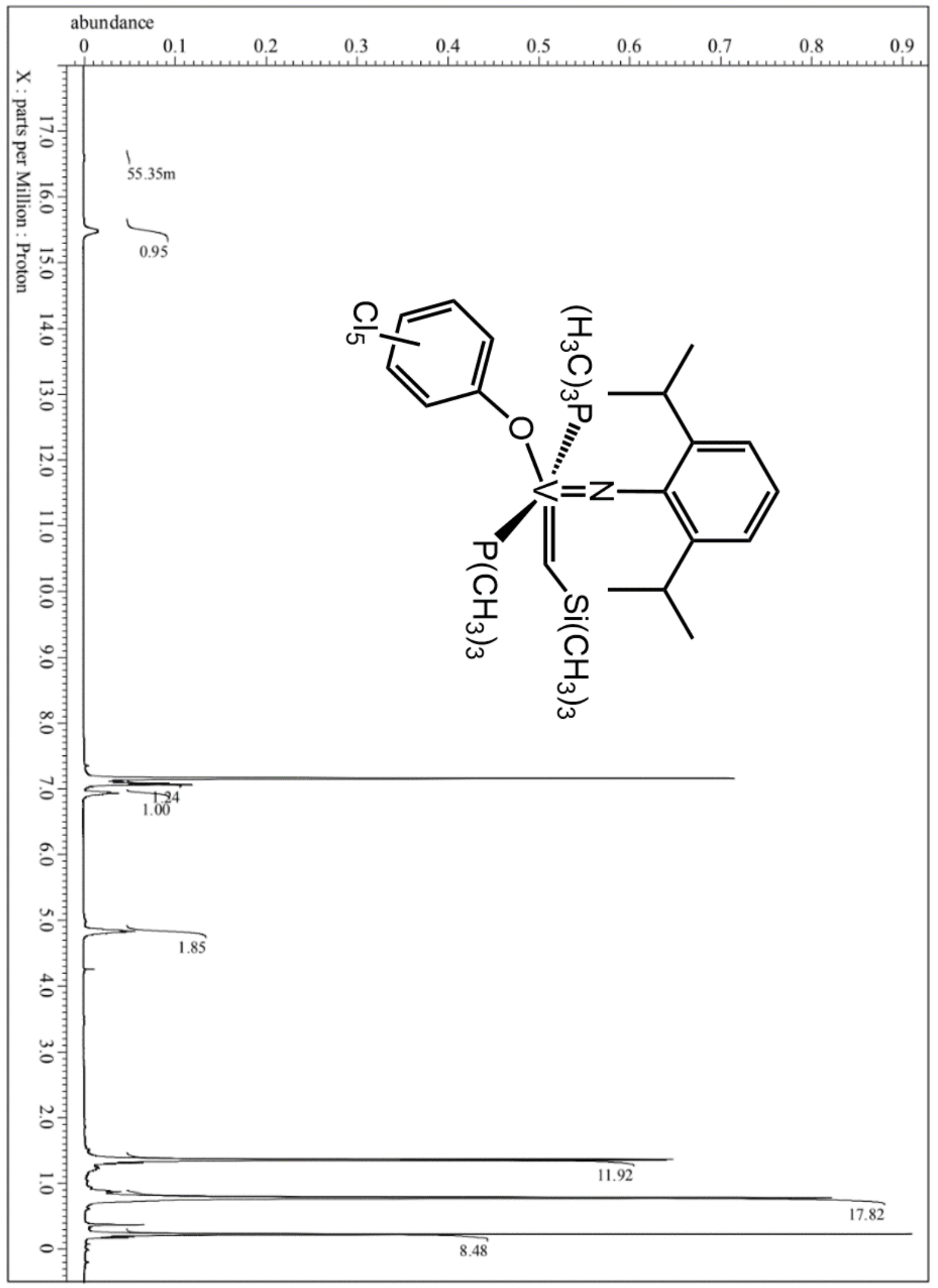

Figure S4. ${ }^{1} \mathrm{H}\left(400 \mathrm{MHz}\right.$, benzene- $\left.d_{6}, 25^{\circ} \mathrm{C}\right) \mathrm{NMR}$ of compound 6. 


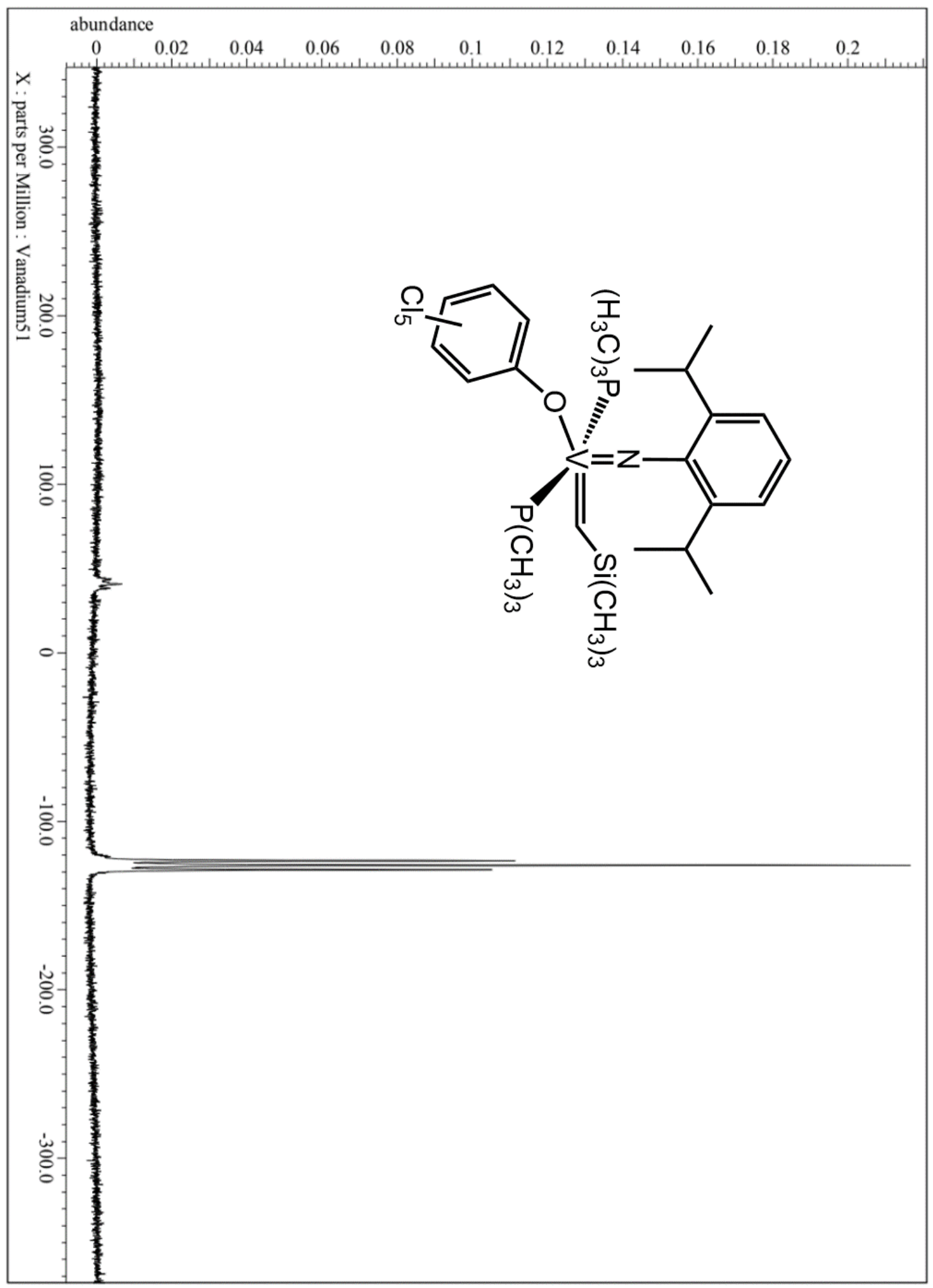

Figure S5. ${ }^{51} \mathrm{~V}\left(105 \mathrm{MHz}\right.$, benzene- $\left.d_{6}, 25^{\circ} \mathrm{C}\right) \mathrm{NMR}$ of compound 6 . 


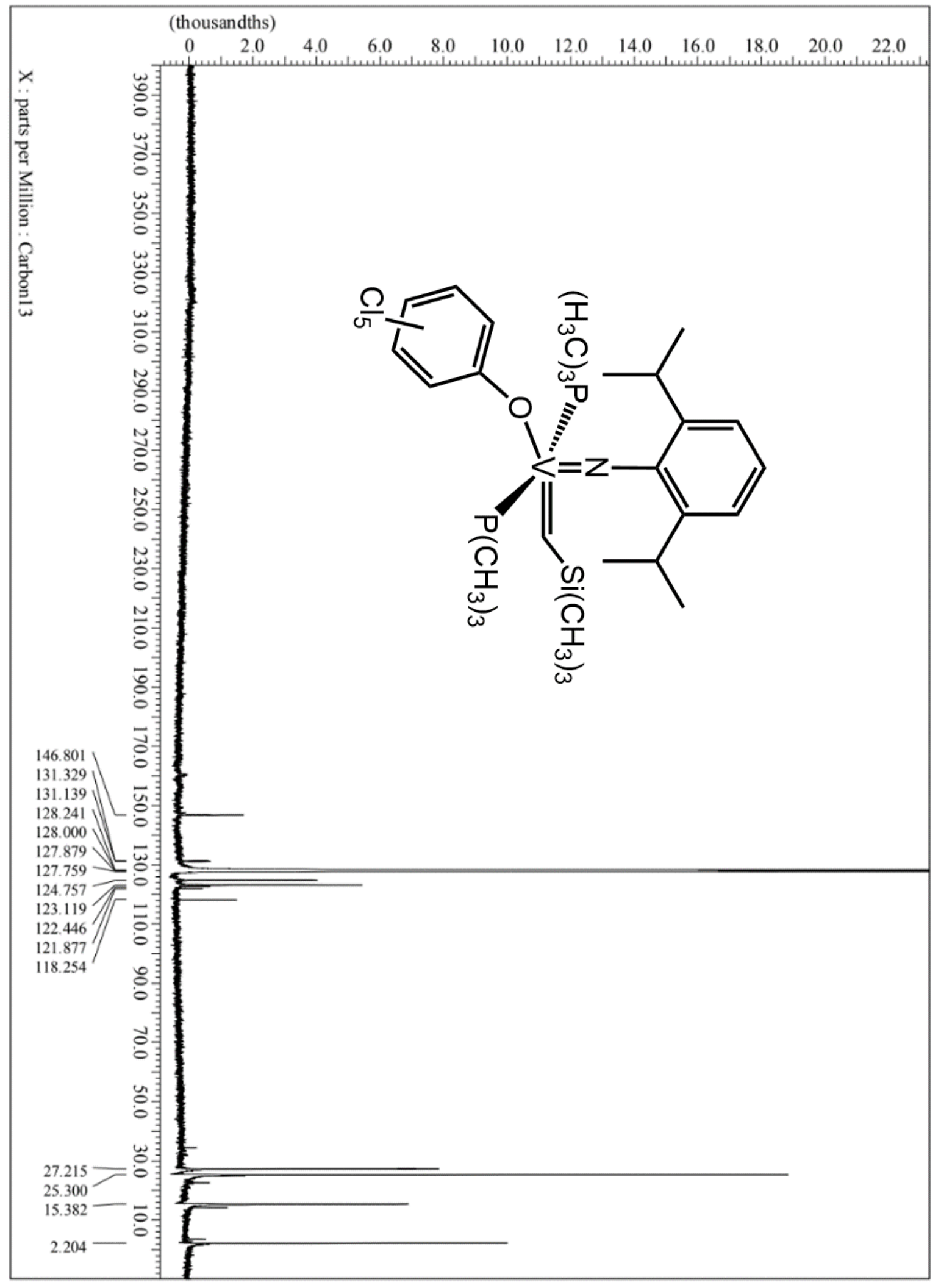

Figure S6. ${ }^{13} \mathrm{C}\left(100 \mathrm{MHz}\right.$, benzene- $\left.d_{6}, 25^{\circ} \mathrm{C}\right) \mathrm{NMR}$ of compound 6 . 


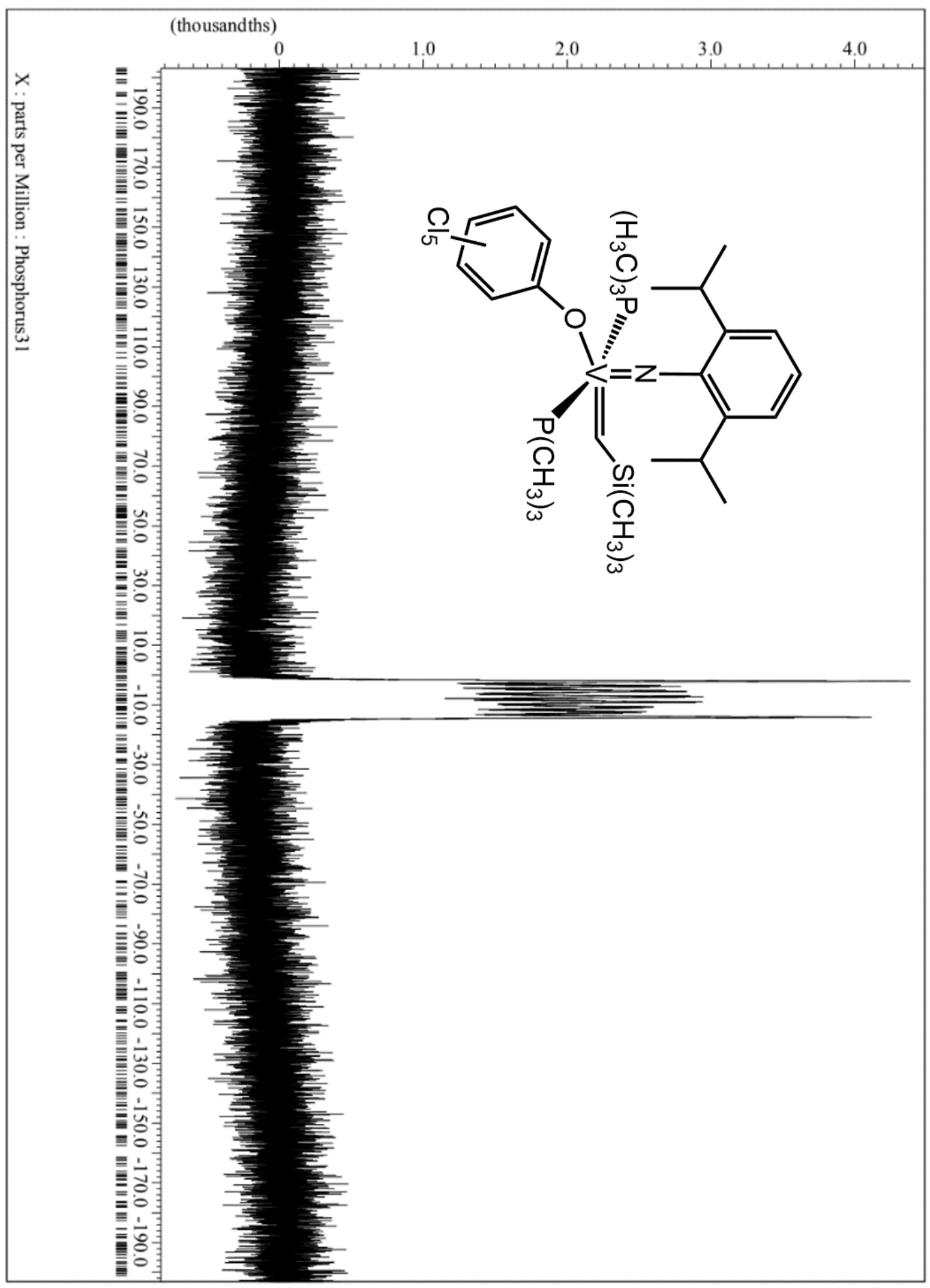

Figure S7. ${ }^{31} \mathrm{P}\left(162 \mathrm{MHz}\right.$, benzene- $\left.d_{6}, 25{ }^{\circ} \mathrm{C}\right) \mathrm{NMR}$ of compound 6 . 


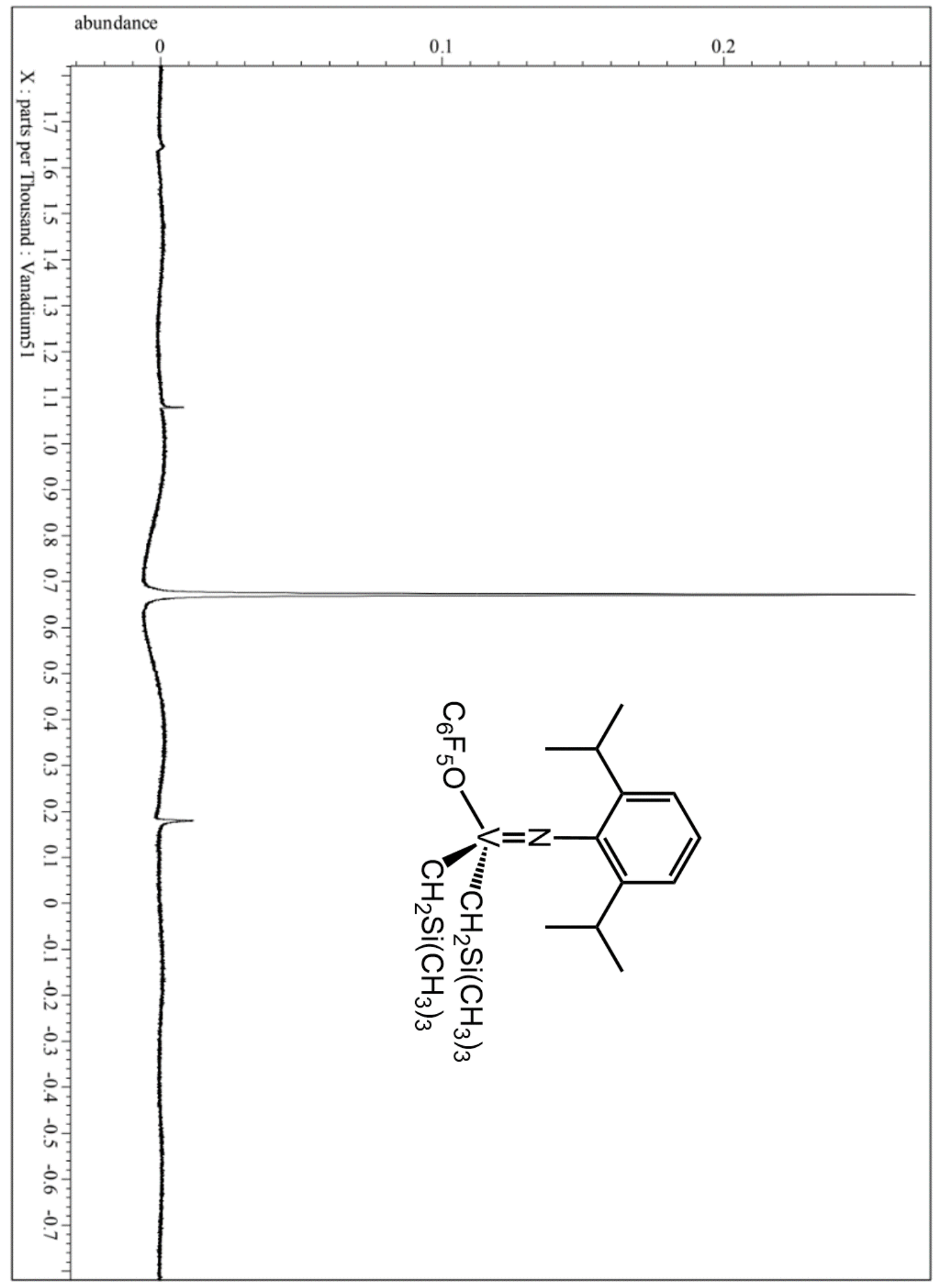

Figure S8. ${ }^{51} \mathrm{~V}\left(105 \mathrm{MHz}\right.$, benzene- $\left.d_{6}, 25^{\circ} \mathrm{C}\right) \mathrm{NMR}$ of compound 19. 


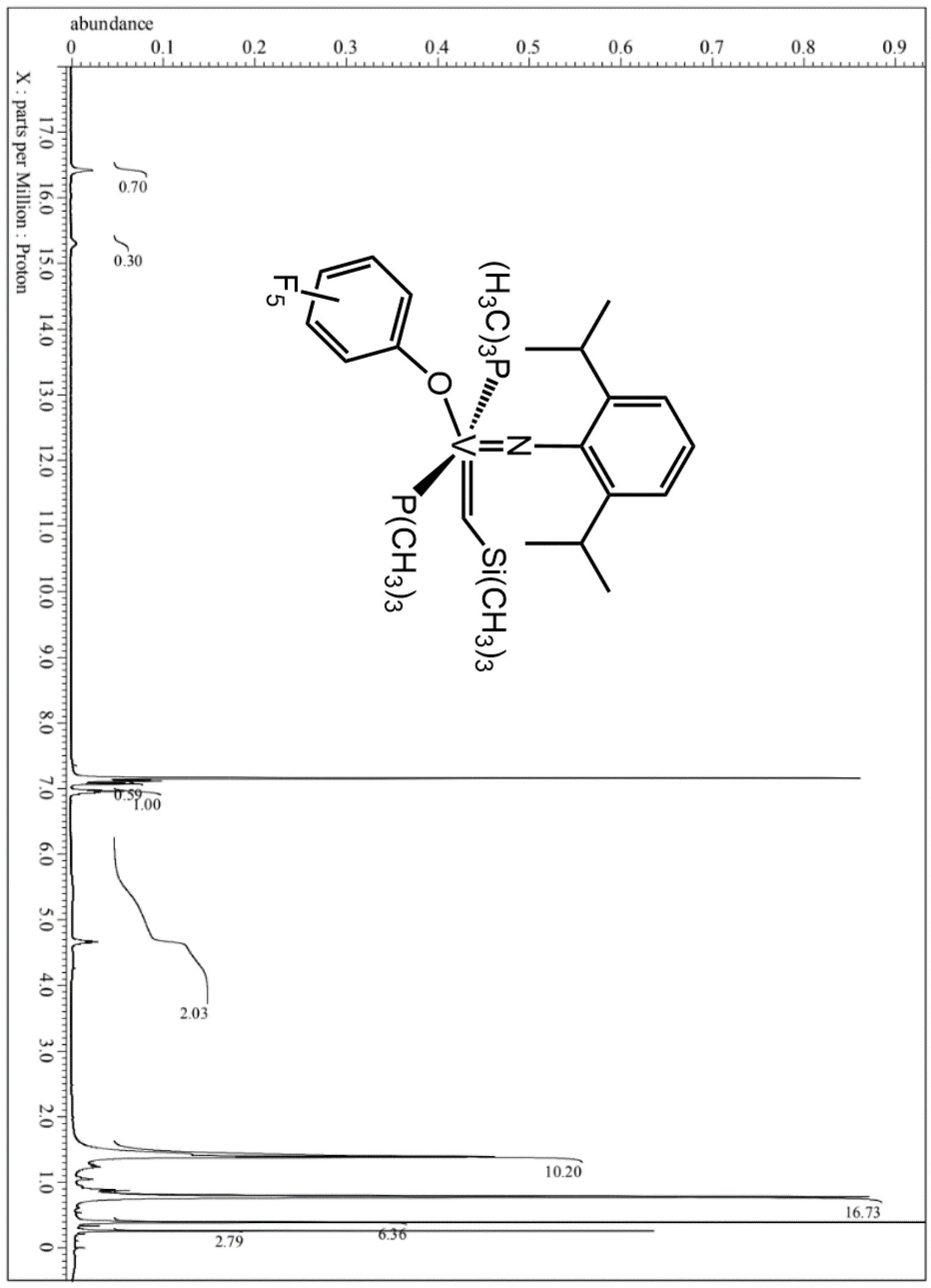

Figure S9. ${ }^{1} \mathrm{H}$ (400 MHz, benzene- $d_{6}, 25{ }^{\circ} \mathrm{C}$ ) NMR of compound 7. 


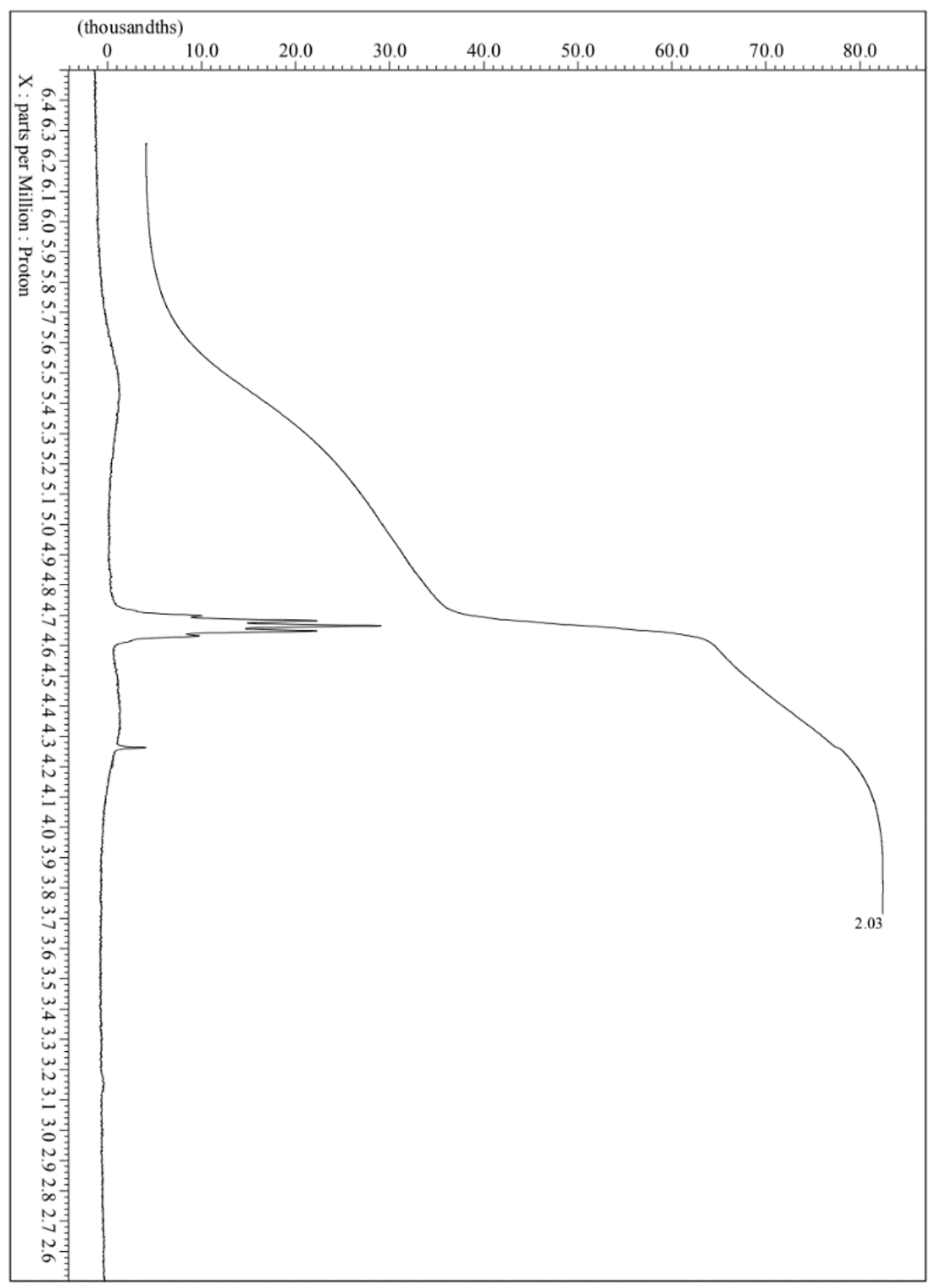

Figure S10. ${ }^{1} \mathrm{H}\left(400 \mathrm{MHz}\right.$, benzene- $d_{6}, 25^{\circ} \mathrm{C}$ ) NMR of compound 7 (methine region). 


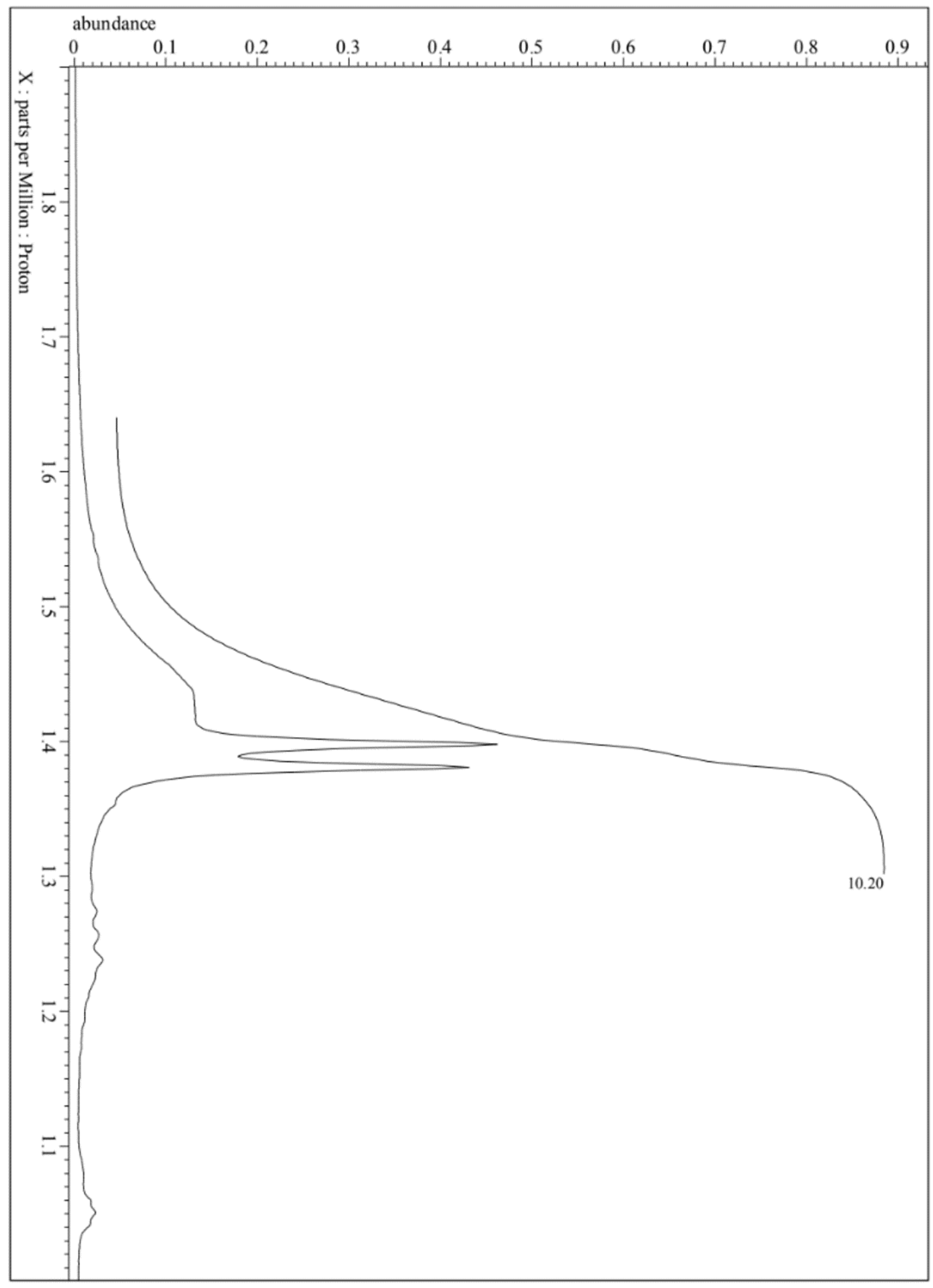

Figure S11. ${ }^{1} \mathrm{H}$ (400 MHz, benzene- $d_{6}, 25^{\circ} \mathrm{C}$ ) NMR of compound 7 (methyl region). 


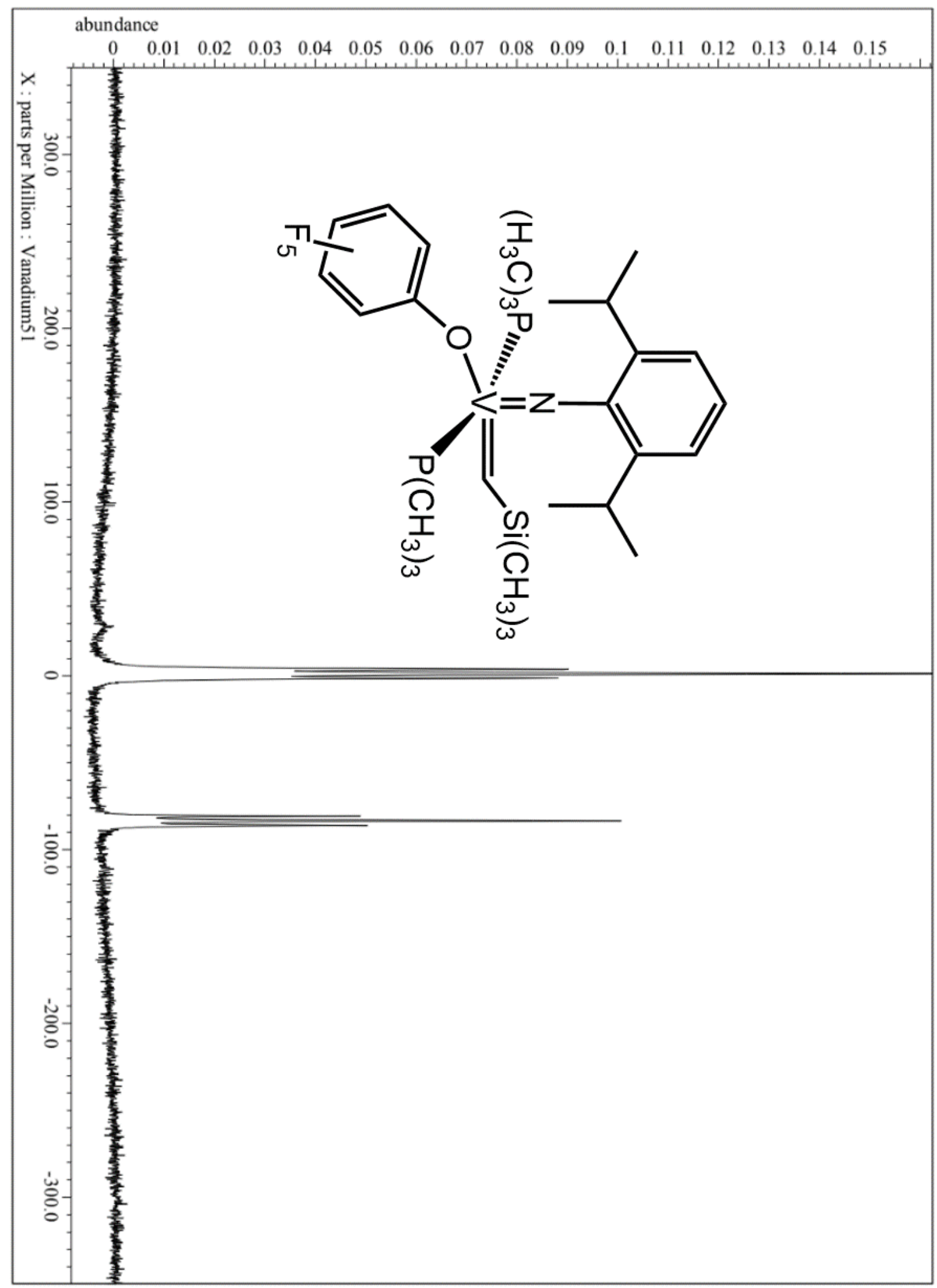

Figure S12. ${ }^{51} \mathrm{~V}\left(105 \mathrm{MHz}\right.$, benzene- $\left.d_{6}, 25{ }^{\circ} \mathrm{C}\right) \mathrm{NMR}$ of compound 7. 


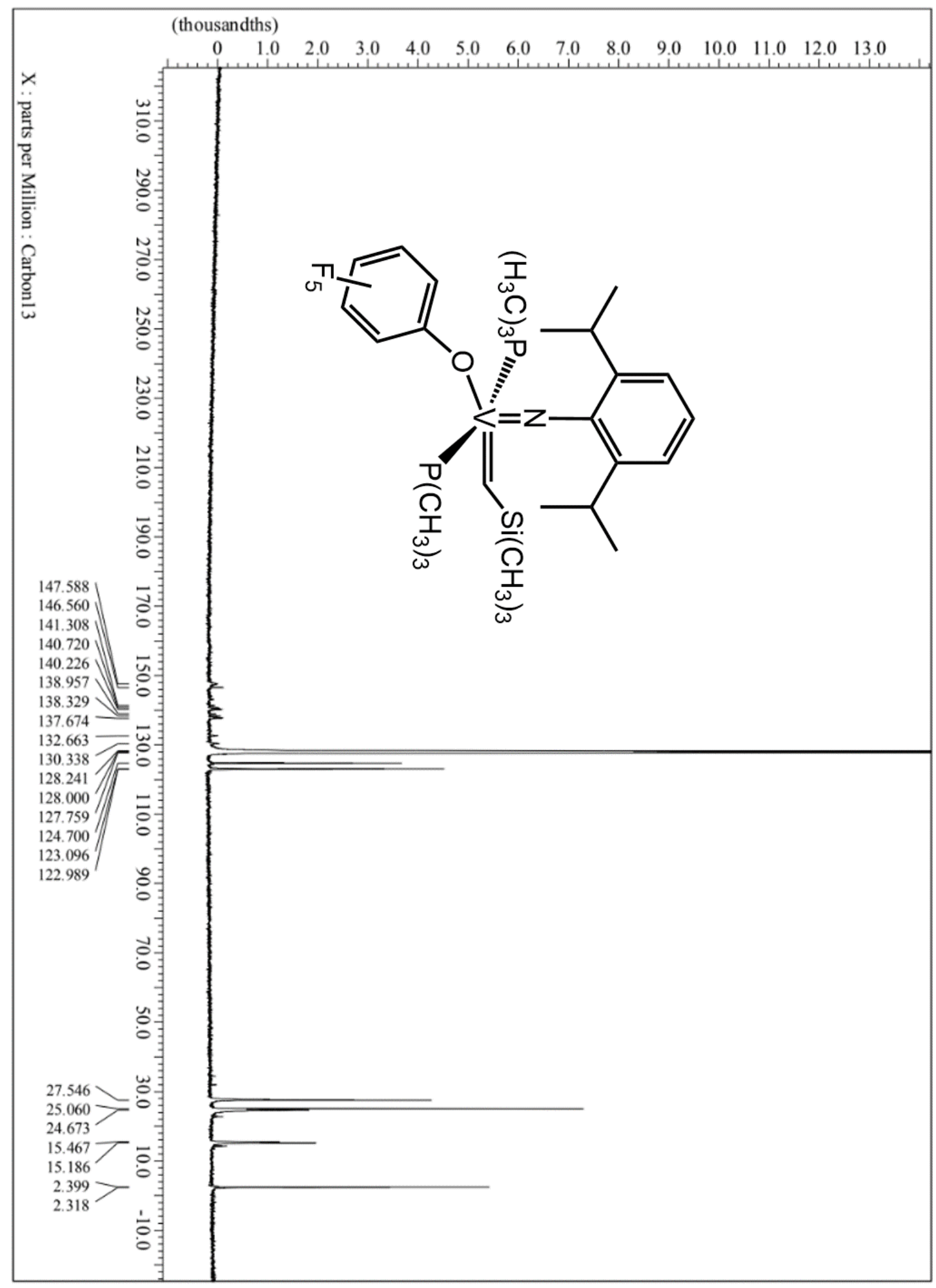

Figure S13. ${ }^{13} \mathrm{C}\left(100 \mathrm{MHz}\right.$, benzene- $\left.d_{6}, 25{ }^{\circ} \mathrm{C}\right) \mathrm{NMR}$ of compound 7. 


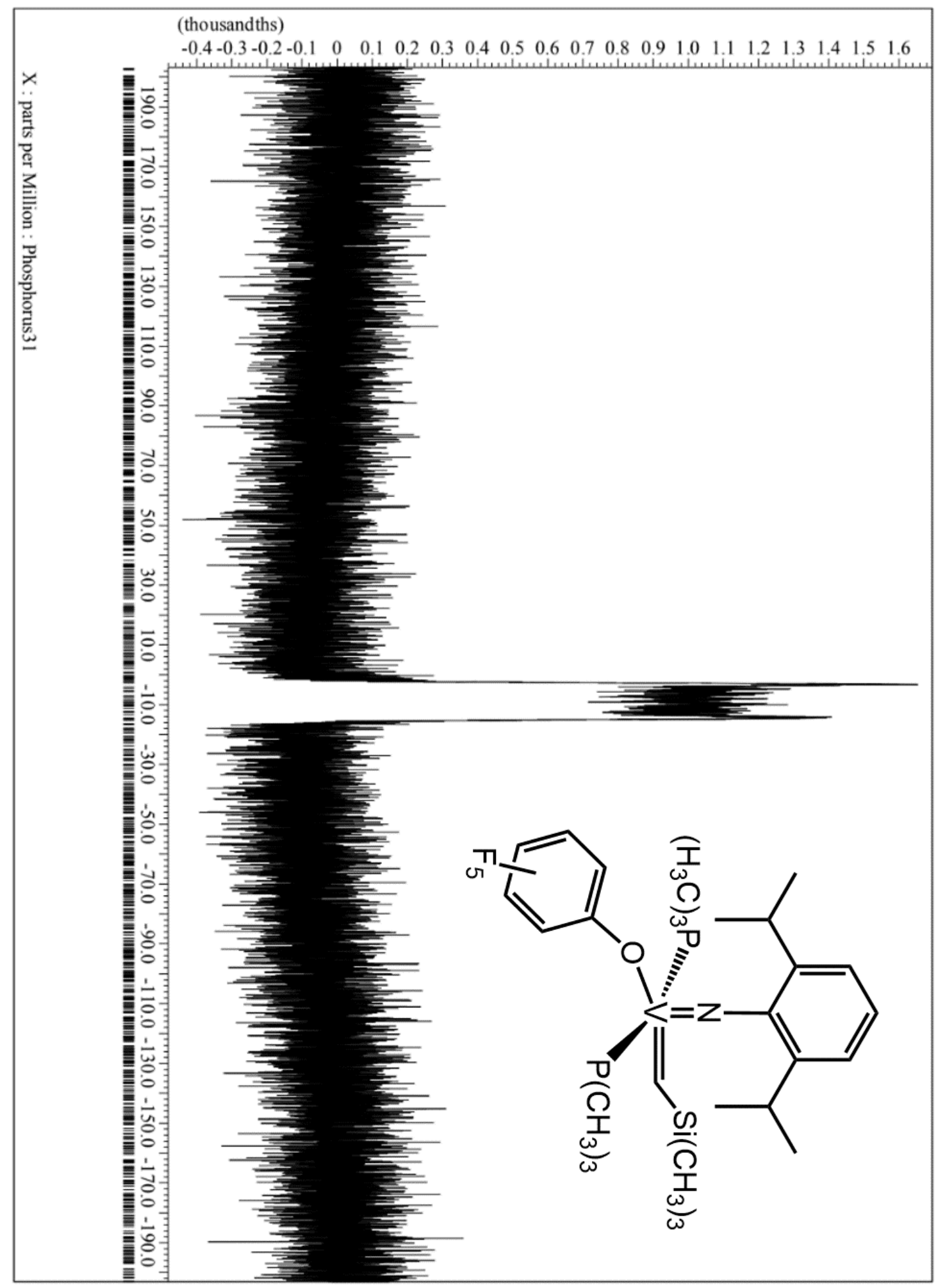

Figure S14. ${ }^{31} \mathrm{P}\left(162 \mathrm{MHz}\right.$, benzene- $\left.d_{6}, 25^{\circ} \mathrm{C}\right) \mathrm{NMR}$ of compound 7. 


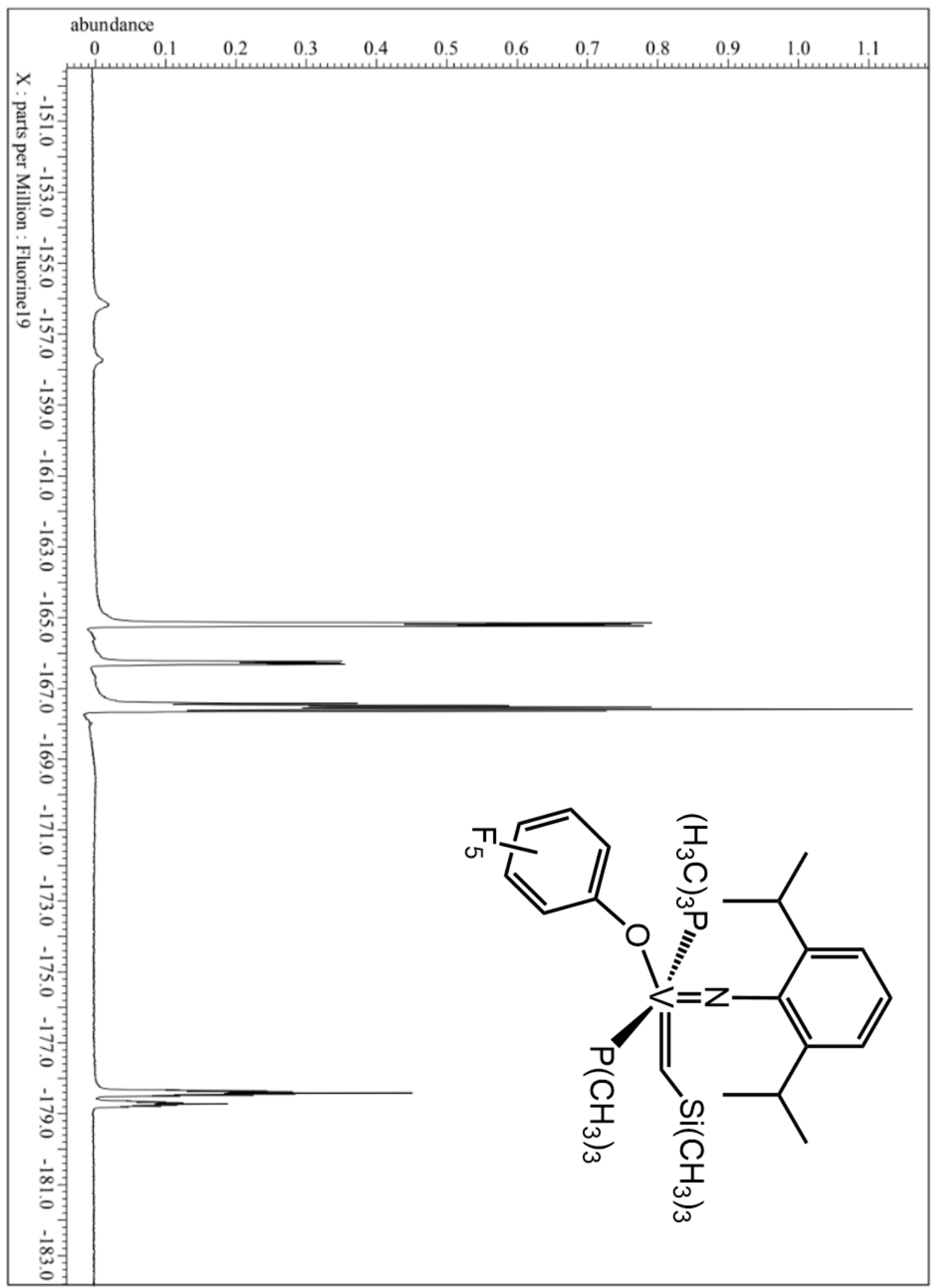

Figure S15. ${ }^{19} \mathrm{~F}$ (376 MHz, benzene- $\left.d_{6}, 25^{\circ} \mathrm{C}\right) \mathrm{NMR}$ of compound 7. 


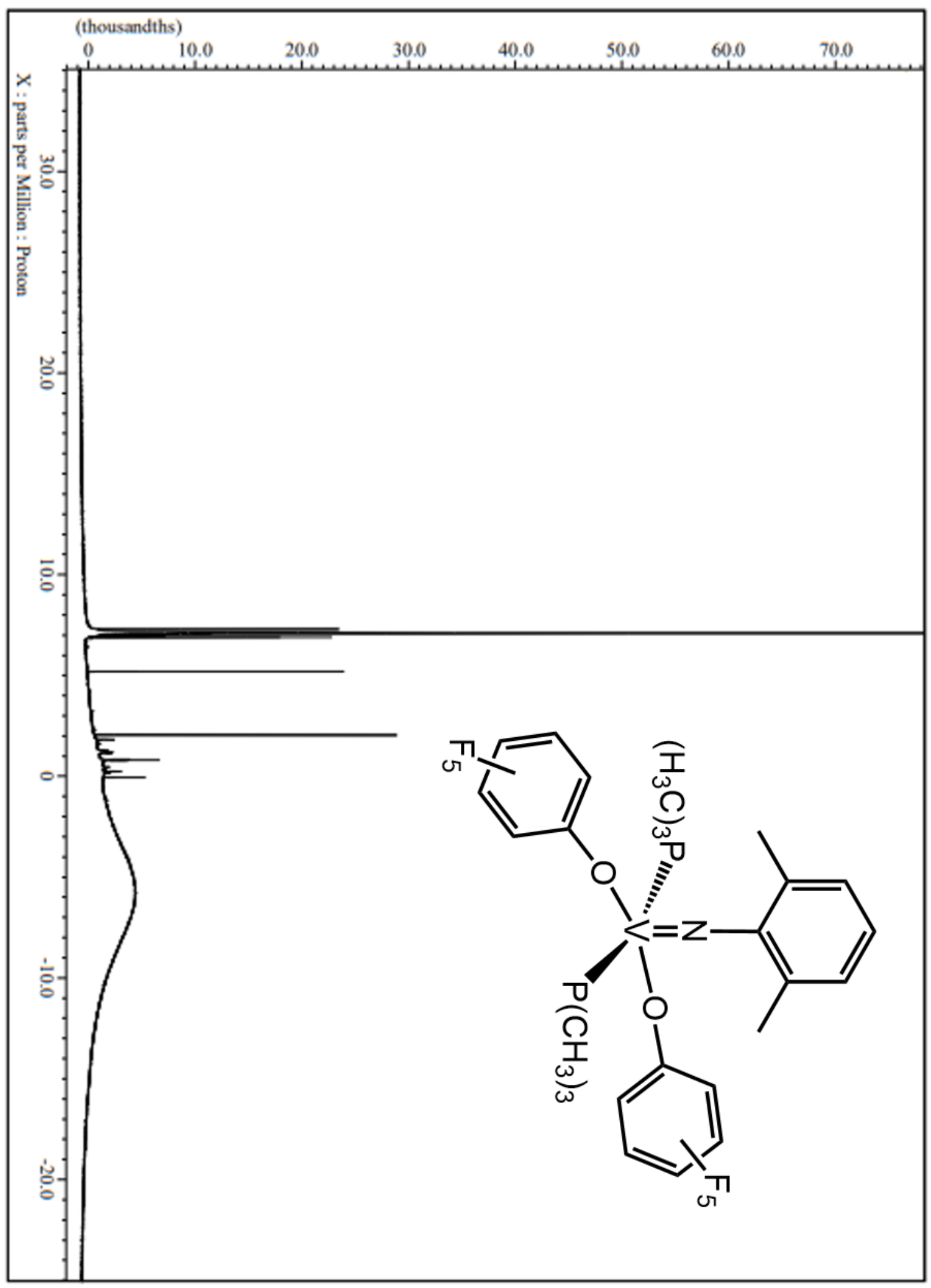

Figure S16. ${ }^{1} \mathrm{H}\left(400 \mathrm{MHz}\right.$, benzene- $\left.d_{6}, 25^{\circ} \mathrm{C}\right) \mathrm{NMR}$ of compound 11. 


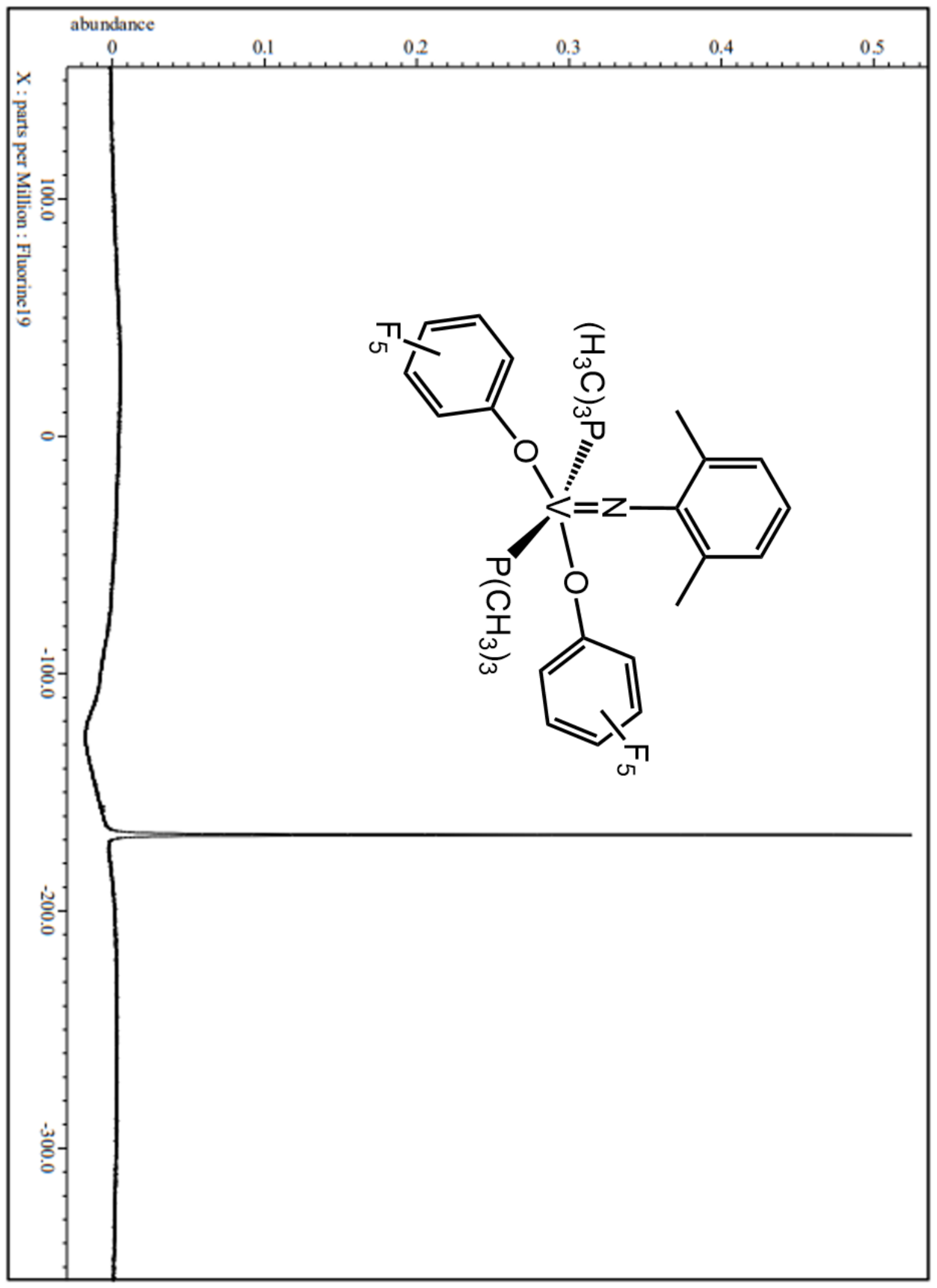

Figure S17. ${ }^{19} \mathrm{~F}$ (376 MHz, benzene- $d_{6}, 25^{\circ} \mathrm{C}$ ) NMR of compound 11 . 


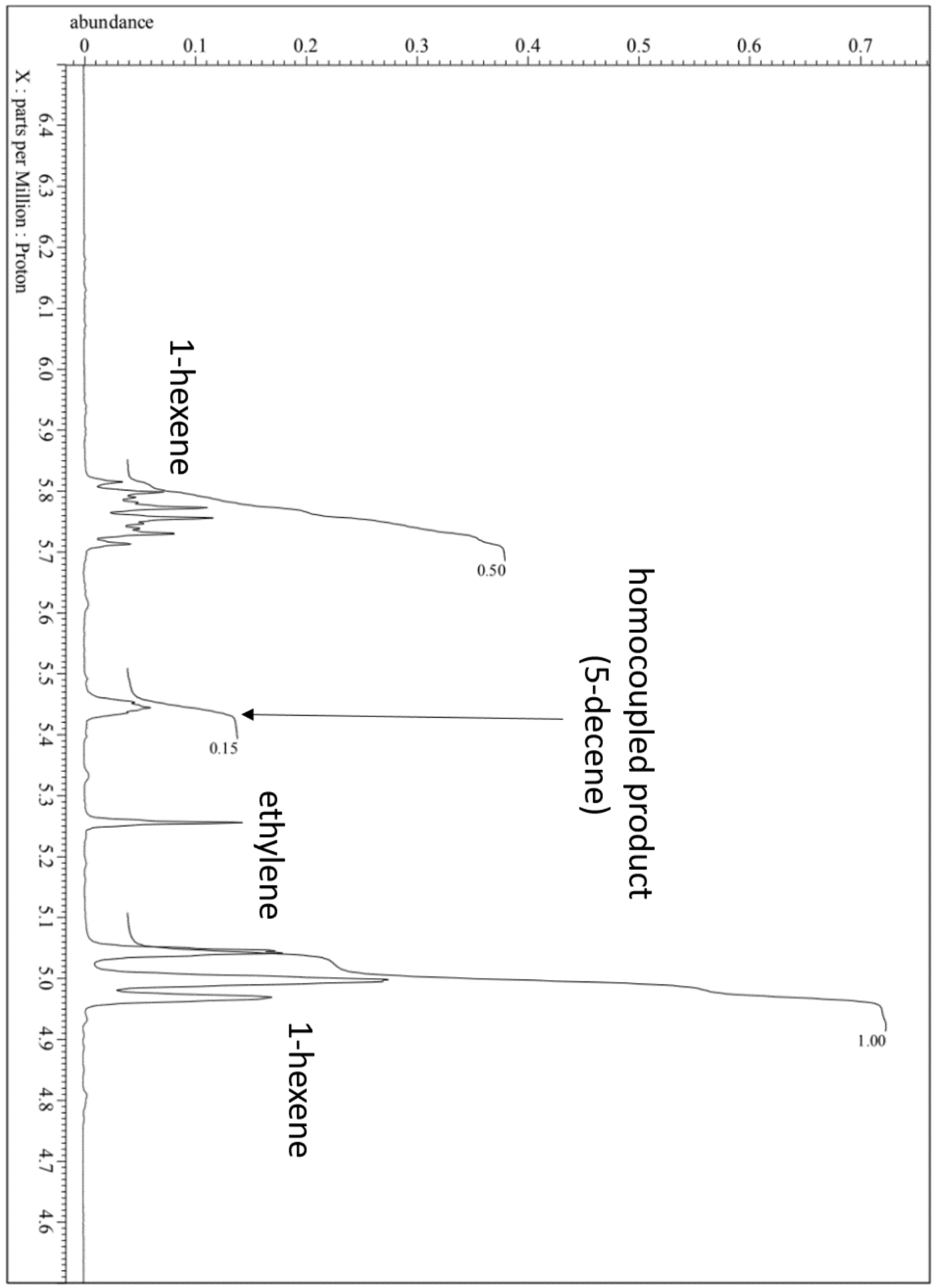

Figure S18. Representative ${ }^{1} \mathrm{H}\left(400 \mathrm{MHz}\right.$, benzene- $d_{6}, 25^{\circ} \mathrm{C}$ ) NMR of SM of 1-hexene. 


\section{EPR SPECTRA}

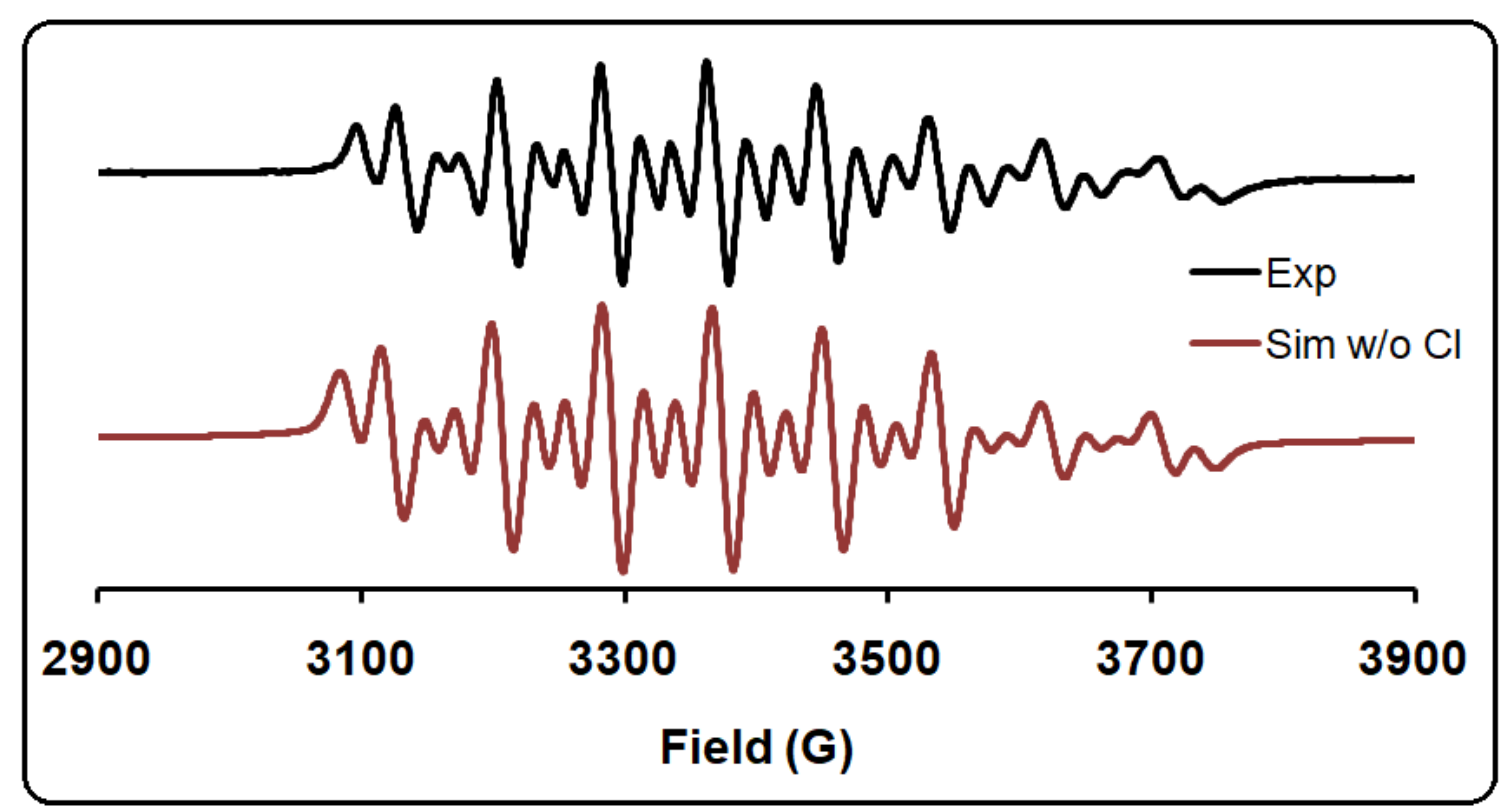

Figure S19: X-band EPR spectra (black trace) of compound 10 in toluene at $298 \mathrm{~K}$ and simulation (maroon trace) done without incorporating the ${ }^{35} \mathrm{Cl}$ nuclei $(I=1.5)$. Frequency: $8.993584 \mathrm{GHz}$, power $=2.00 \mathrm{~mW}$, Mod Width $=0.2 \mathrm{mT}$, time-constant $=0.03 \mathrm{~s}$. Simulation provides: $g_{\text {iso }}=1.881 ; A_{\text {iso }}(\mathrm{V})=220 \mathrm{MHz}, A_{\text {iso }}(\mathrm{N})$ $=40 \mathrm{MHz}, A_{\text {iso }}(\mathrm{P} 1$ and $\mathrm{P} 2)=75 \mathrm{MHz}$. The exercise shows the moderate contribution of ${ }^{35} \mathrm{Cl}$ nuclei on the EPR spectrum.

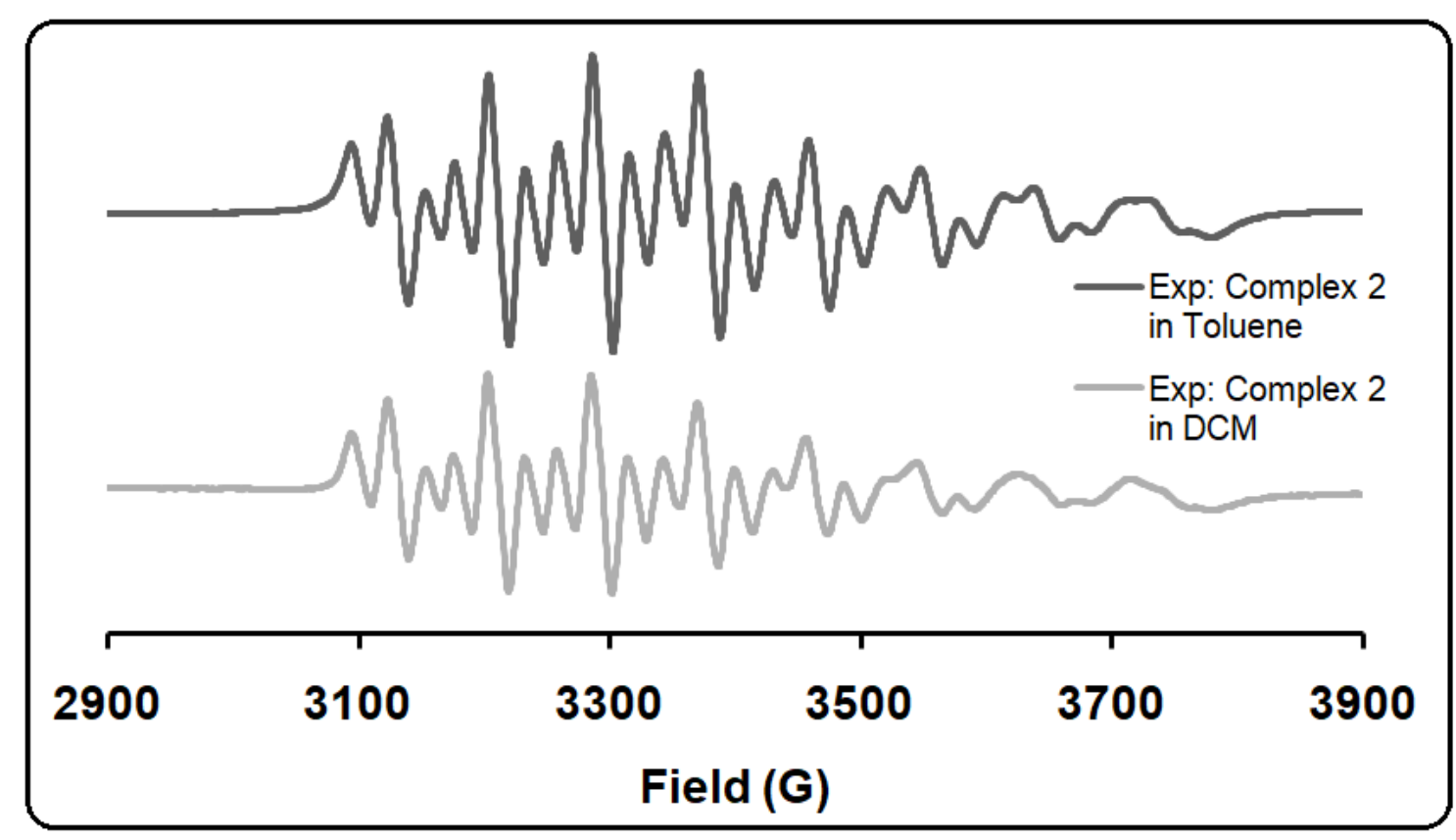

Figure S20. Comparison of X-band EPR spectra of compound 2 in toluene (isolated, black trace) and in $\mathrm{CH}_{2} \mathrm{Cl}_{2}$ (in situ, grey trace) at $298 \mathrm{~K}$. 


\section{GC-FID}

\section{$<$ Chromatogram>}

uV

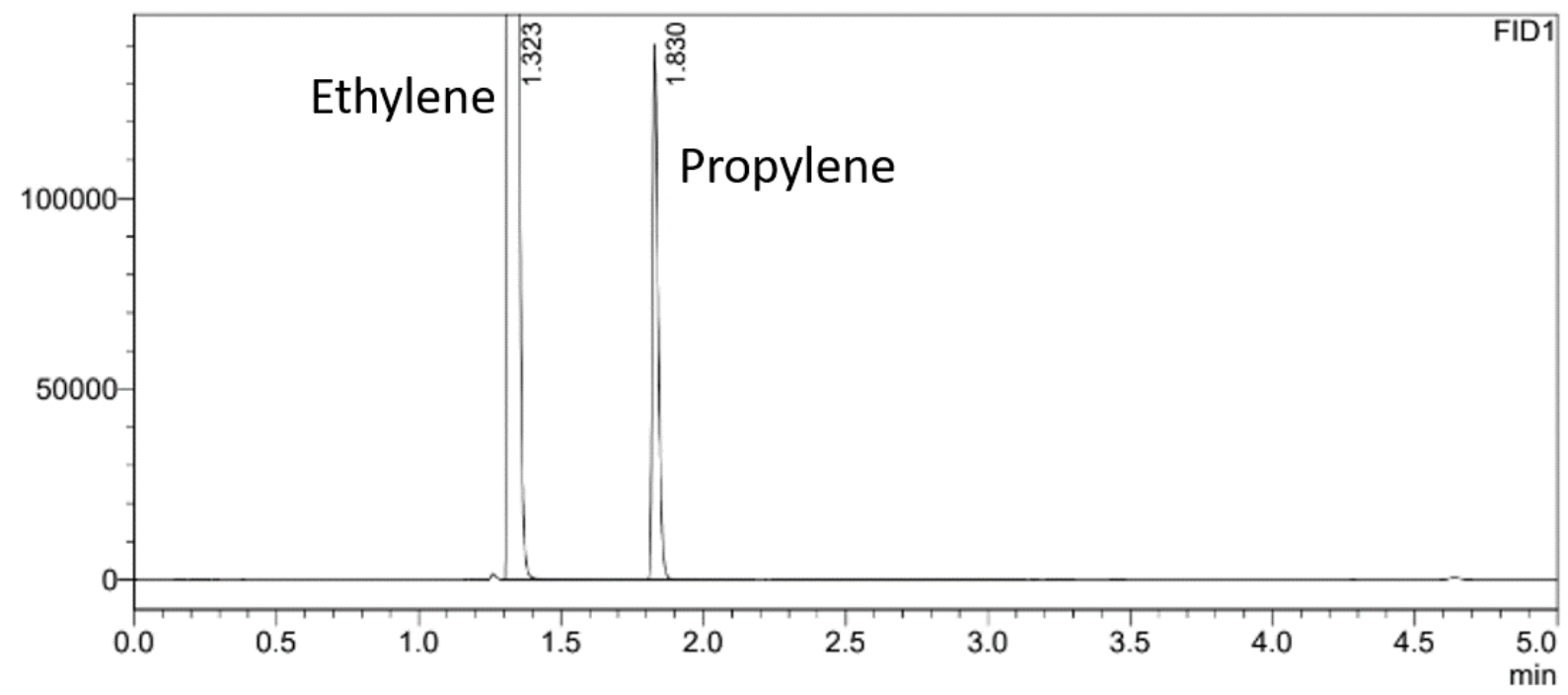

\section{<Peak Table>}

\begin{tabular}{|c|c|c|c|c|c|c|c|}
\hline $\begin{array}{l}\text { FID1 } \\
\text { Peak\# }\end{array}$ & & & & & & & \\
\hline $\begin{array}{r}\text { Peak\# } \\
1\end{array}$ & 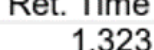 & $\begin{array}{l}\text { Area } \\
4425764\end{array}$ & $\begin{array}{l}\text { Helght } \\
3535885\end{array}$ & $\begin{array}{l}\text { Conc. } \\
95906\end{array}$ & Unit & Mark & Name \\
\hline 2 & 1.830 & 188911 & 135710 & 4.094 & & & \\
\hline Total & & 4614675 & 3671595 & & & & \\
\hline
\end{tabular}

Figure 21. GC-FID of headspace of reaction of compound 1 with ethylene gas.

\section{COMPUTATIONAL DATA AND FIGURES}

Table S1. Enthalpy and Gibbs free energies B3P86/6-311+G(d) at $298.15 \mathrm{~K}$ of the computed molecules. $[\mathrm{V}]=\left\{\left[\mathrm{N}-2,6-\left(\mathrm{CH}_{3}\right)_{2} \mathrm{C}_{6} \mathrm{H}_{3}\right]\left[\mathrm{P}\left(\mathrm{CH}_{3}\right)_{3}\right]_{2} \mathrm{~V}\right.$ fragment.

\begin{tabular}{|c|c|c|c|c|}
\hline Compound & Charge & Multiplicity & $\begin{array}{c}\text { Enthalpy } \\
\text { (in Hartree) }\end{array}$ & $\begin{array}{c}\text { Gibbs Free Energy } \\
\text { (in Hartree) }\end{array}$ \\
\hline$\left(\mathrm{OC}_{6} \mathrm{Cl}_{5}\right)[\mathrm{V}](\mathrm{CH}-\mathrm{TMS})(\mathbf{1})$ & 0 & 1 & -5290.443471 & -5290.578147 \\
\hline$\left.\left(\mathrm{OC}_{6} \mathrm{Cl}\right)_{5}\right)[\mathrm{V}](\mathrm{Cl})(\mathbf{1 0})$ & 0 & 2 & -5302.322822 & -5302.443819 \\
\hline$\left(\mathrm{OC}_{6} \mathrm{~F}_{5}\right)[\mathrm{V}](\mathrm{CH}-\mathrm{TMS})(\mathbf{5})$ & 0 & 1 & -3487.804012 & -3487.936908 \\
\hline$\left(\mathrm{OC}_{6} \mathrm{~F}_{5}\right)_{2}[\mathrm{~V}](\mathbf{1 1})$ & 0 & 2 & -3843.855577 & -3843.996188 \\
\hline$[\mathrm{V}](\mathrm{CH}-\mathrm{TMS})(\mathbf{1 5})$ & 0 & 2 & -2682.990554 & -2683.099928 \\
\hline$[\mathrm{V}](\mathbf{1 4})$ & 0 & 2 & -2234.168419 & -2234.255289 \\
\hline Ethylene & 0 & 1 & -78.836993 & -78.863159 \\
\hline Propene & 0 & 1 & -118.281391 & -118.311436 \\
\hline Vinyl-TMS & 0 & 1 & -488.188191 & -488.233252 \\
\hline
\end{tabular}




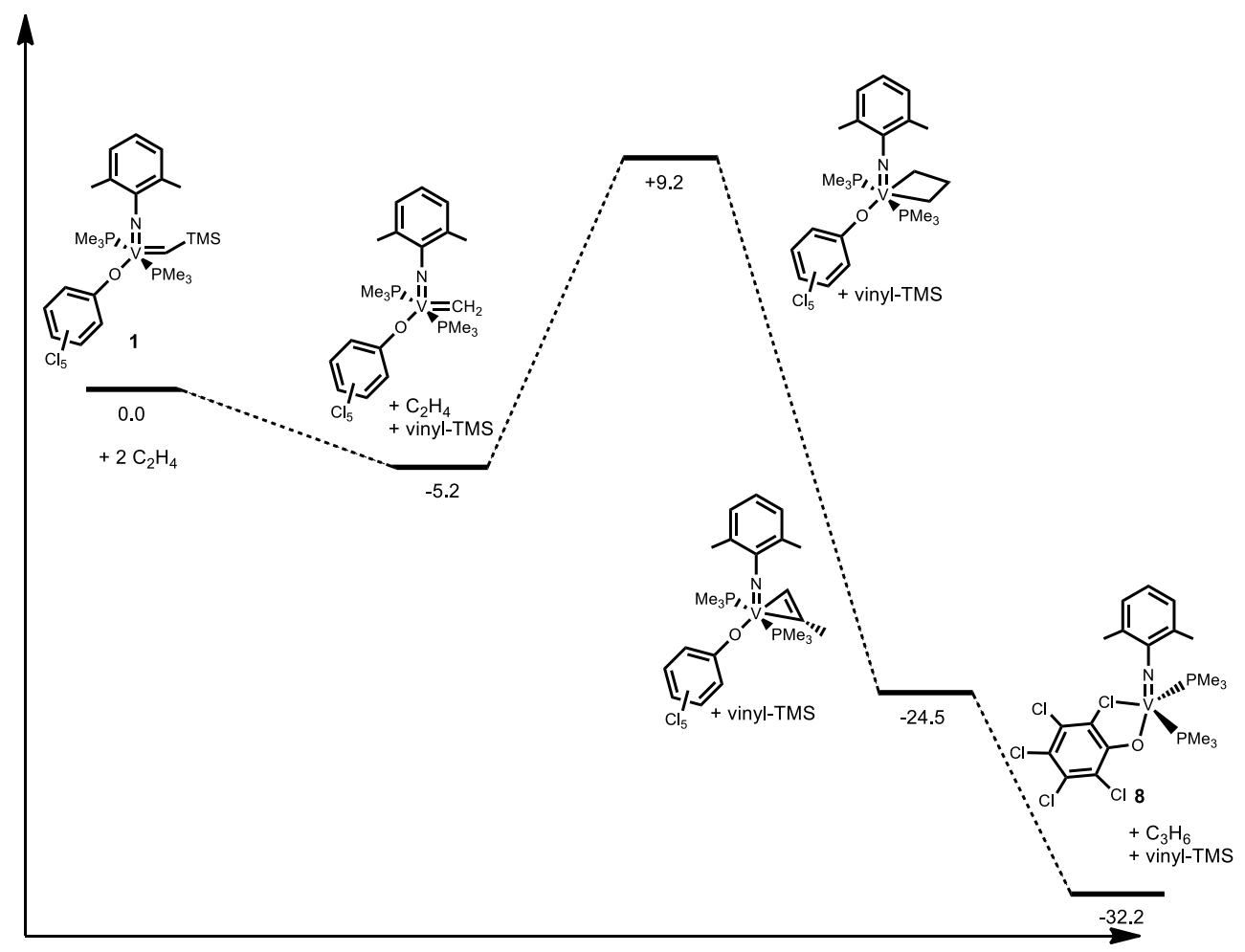

Figure S22: DFT [B3P86/6-311+G(d)] predicted relative free energies for decomposition of 1 to form proposed intermediate 8 . Energies in $\mathrm{kcal} / \mathrm{mol}$ at $298.15 \mathrm{~K}$.

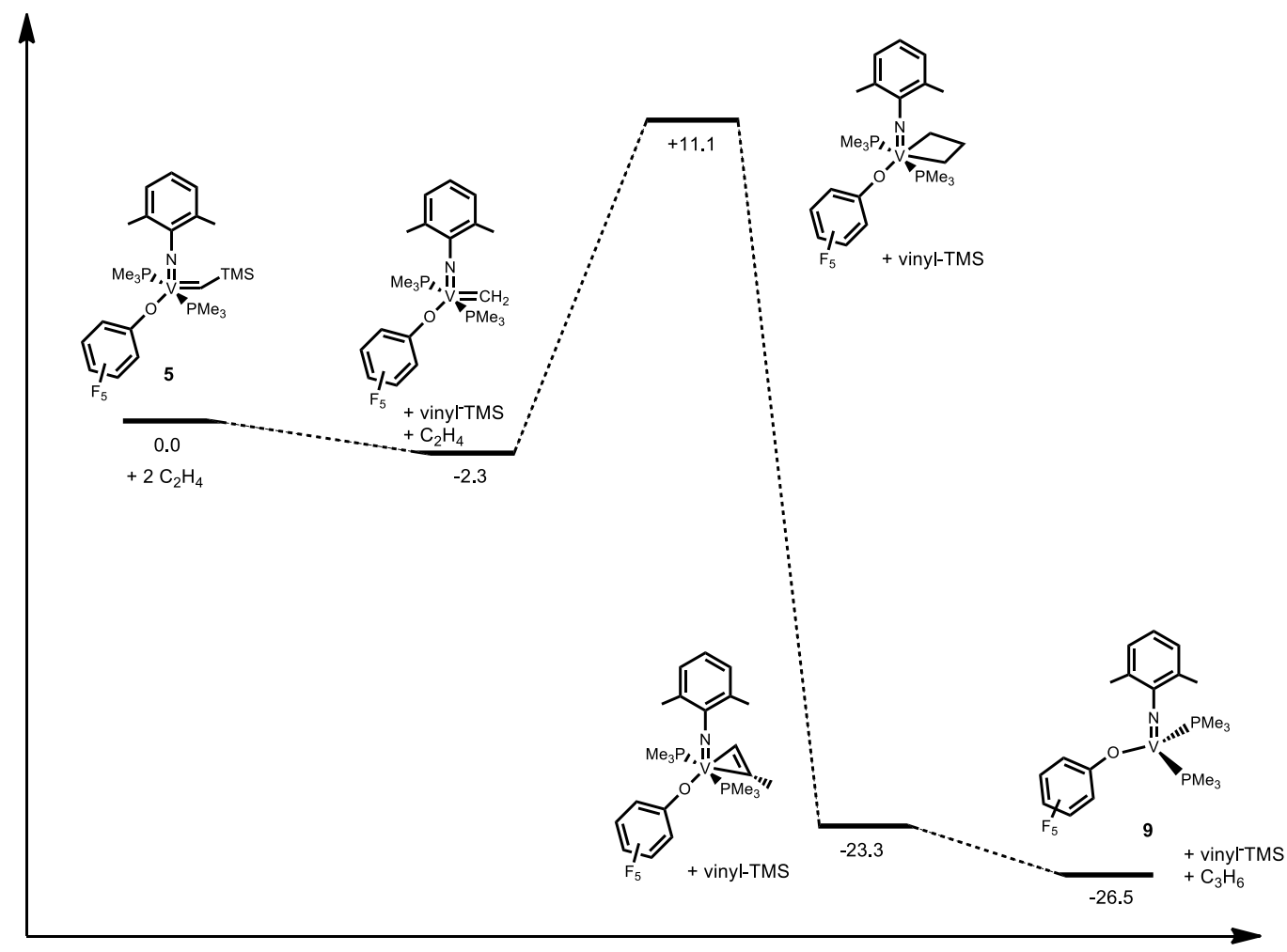

Figure S23: DFT [B3P86/6-311+G(d)] predicted relative free energies for decomposition of 5 to form proposed intermediate 9 . Energies in $\mathrm{kcal} / \mathrm{mol}$ at $298.15 \mathrm{~K}$. 


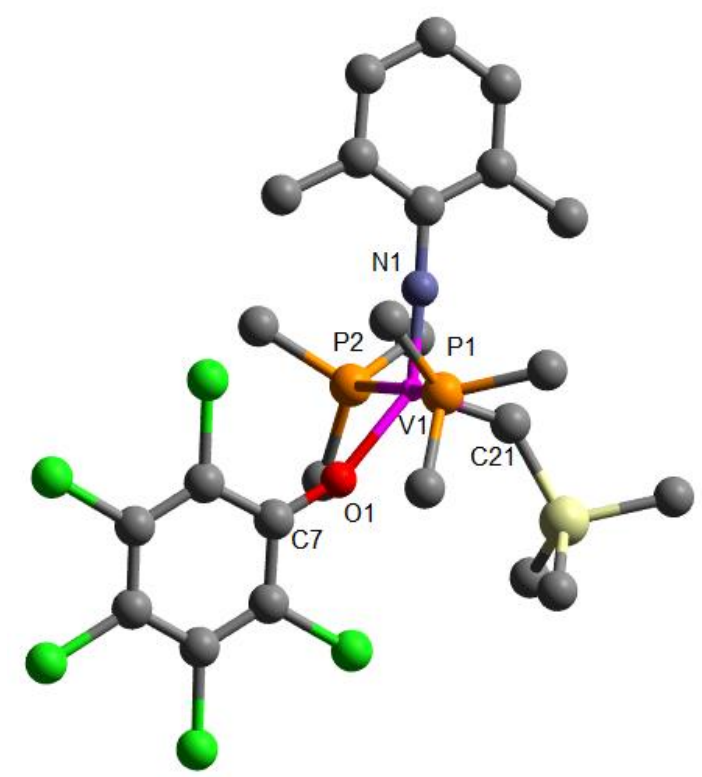

Figure S24. Geometry optimized structure of $\left(\mathrm{OC}_{6} \mathrm{Cl}_{5}\right)[\mathrm{V}](\mathrm{CH}-\mathrm{TMS})(\mathbf{1})$ at the $\mathrm{B} 3 \mathrm{P} 86 / 6-311+\mathrm{G}(\mathrm{d})$ level of theory with charge $=0$, multiplicity $=1$. Selected calculated bond distances $(\AA)$ and angles $\left(^{\circ}\right)$ for $\left(\mathrm{OC}_{6} \mathrm{Cl}_{5}\right)[\mathrm{V}](\mathrm{CH}-\mathrm{TMS})(\mathbf{1})$ : V1-N1, 1.679; V1-O1: 1.964; V1-P1: 2.497; V1-P2: 2.478; V1-C21: 1.828; O1-C7, 1.291; P1-V1-P2, 167.68.

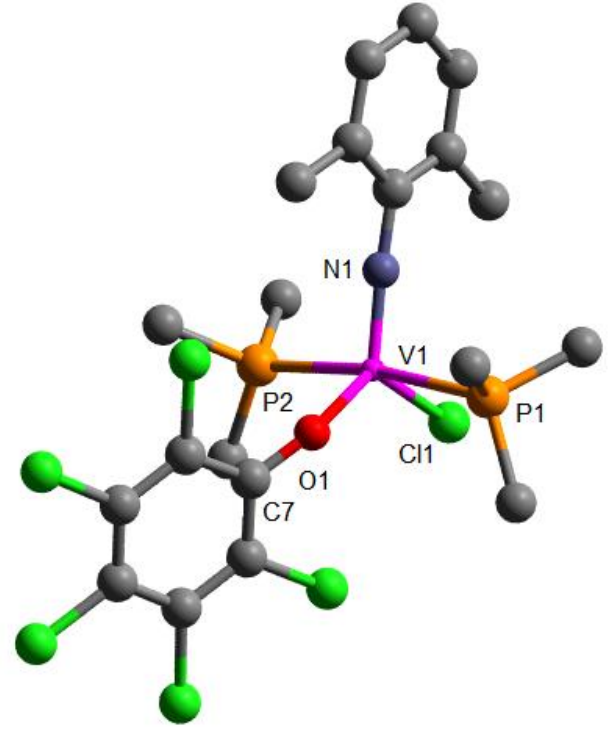

Figure S25. Geometry optimized structure of $\left(\mathrm{OC}_{6} \mathrm{Cl}_{5}\right)[\mathrm{V}](\mathrm{Cl})(\mathbf{1 0})$ at the B3P86/6-311+G(d) level of theory with charge $=0$, multiplicity $=2$. Selected calculated bond distances $(\AA)$ and angles $\left({ }^{\circ}\right)$ for $\left(\mathrm{OC}_{6} \mathrm{Cl}_{5}\right)[\mathrm{V}](\mathrm{Cl})(\mathbf{1 0})$ : V1-N1, 1.661; V1-O1: 1.935; V1-P1: 2.499; V1-P2: 2.516; V1-Cl1: 2.300; O1-C7, 1.299; P1-V1-P2, 170.89. 


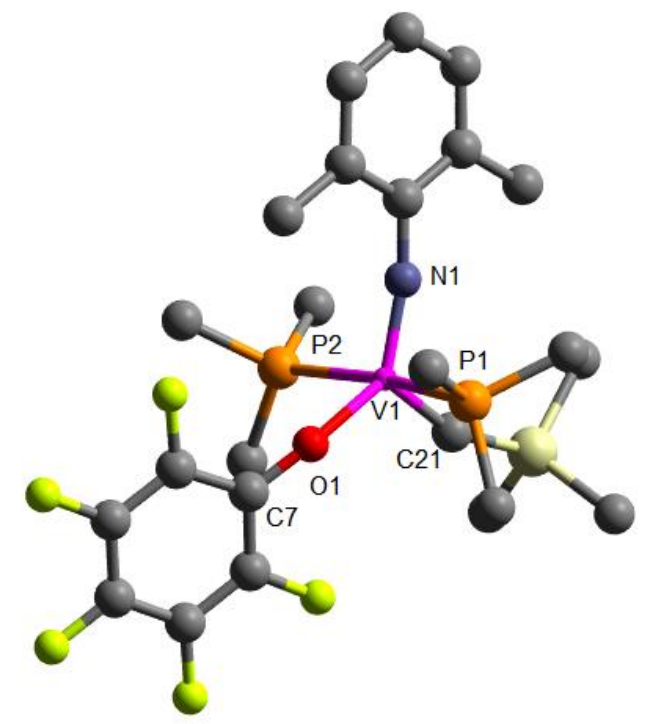

Figure S26. Geometry optimized structure of $\left(\mathrm{OC}_{6} \mathrm{~F}_{5}\right)[\mathrm{V}](\mathrm{CH}-\mathrm{TMS})(5)$ at the $\mathrm{B} 3 \mathrm{P} 86 / 6-311+\mathrm{G}(\mathrm{d})$ level of theory with charge $=0$, multiplicity $=1$. Selected calculated bond distances $(\AA)$ and angles $\left({ }^{\circ}\right)$ for $\left(\mathrm{OC}_{6} \mathrm{~F}_{5}\right)[\mathrm{V}](\mathrm{CH}-\mathrm{TMS})$ (5): V1-N1, 1.674; V1-O1: 1.965; V1-P1: 2.481; V1-P2: 2.471; V1-C21: 1.811; O1-C7, 1.301; P1-V1-P2, 168.99.

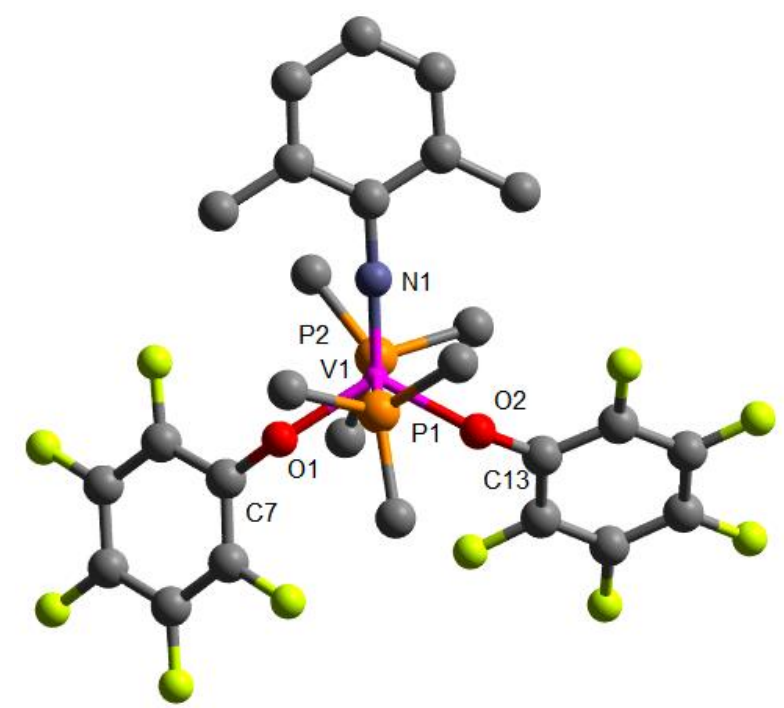

Figure S27. Geometry optimized structure of $\left(\mathrm{OC}_{6} \mathrm{~F}_{5}\right)_{2}[\mathrm{~V}](\mathbf{1 1})$ at the $\mathrm{B} 3 \mathrm{P} 86 / 6-311+\mathrm{G}(\mathrm{d})$ level of theory with charge $=0$, multiplicity $=2$. Selected calculated bond distances $(\AA)$ and angles $\left({ }^{\circ}\right)$ for $\left(\mathrm{OC}_{6} \mathrm{~F}_{5}\right)_{2}[\mathrm{~V}]$ (11): V1-N1, 1.665; V1-O1: 1.919; V1-O2: 1.919; V1-P1: 2.544; V1-P2: 2.512; O1-C7, 1.306; O2-C13: 1.307; P1-V1-P2, 174.14. 


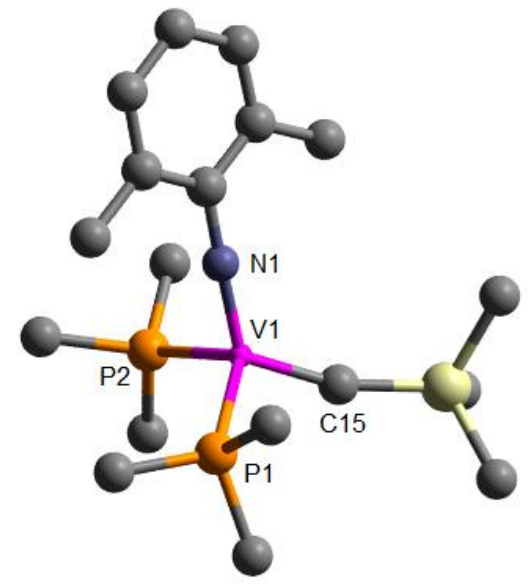

Figure S28. Geometry optimized structure of $[\mathrm{V}](\mathrm{CH}-\mathrm{TMS})(\mathbf{1 5})$ at the B3P86/6-311+G(d) level of theory with charge $=0$, multiplicity $=2$. Selected calculated bond distances $(\AA)$ and angles $\left({ }^{\circ}\right)$ for $[\mathrm{V}](\mathrm{CH}-\mathrm{TMS})$ (15): V1-N1, 1.701; V1-P1: 2.450; V1-P2: 2.431; V1-C15: 1.820; P1-V1-P2, 118.83.

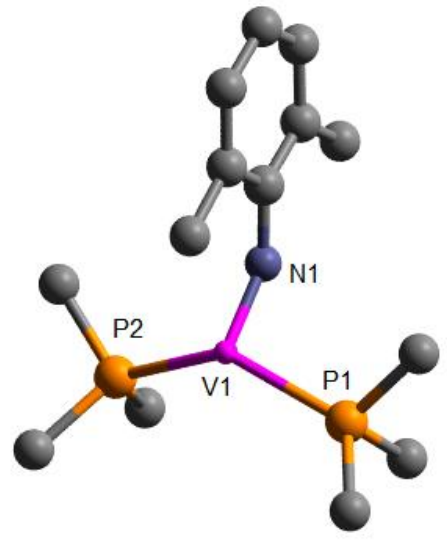

Figure S29. Geometry optimized structure of [V] (14) at the B3P86/6-311+G(d) level of theory with charge $=0$, multiplicity $=2$. Selected calculated bond distances $(\AA)$ and angles $\left(^{\circ}\right)$ for $[\mathrm{V}](\mathbf{1 4})$ : V1-N1, 1.717; V1P1: 2.398; V1-P2: 2.398; P1-V1-P2, 135.84. 

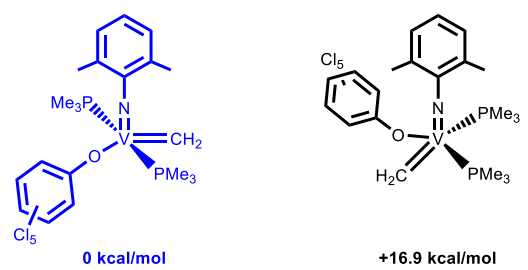

Chart S1. Calculated relative free energies of the possible isomers of $\left(\mathrm{OC}_{6} \mathrm{Cl}_{5}\right)[\mathrm{V}]\left(\mathrm{CH}_{2}\right)$ at the B3P86/6$311+\mathrm{G}(\mathrm{d})$ level of theory in $\mathrm{kcal} / \mathrm{mol}$ at $298.15 \mathrm{~K}$. The lowest energy isomer is show in blue.

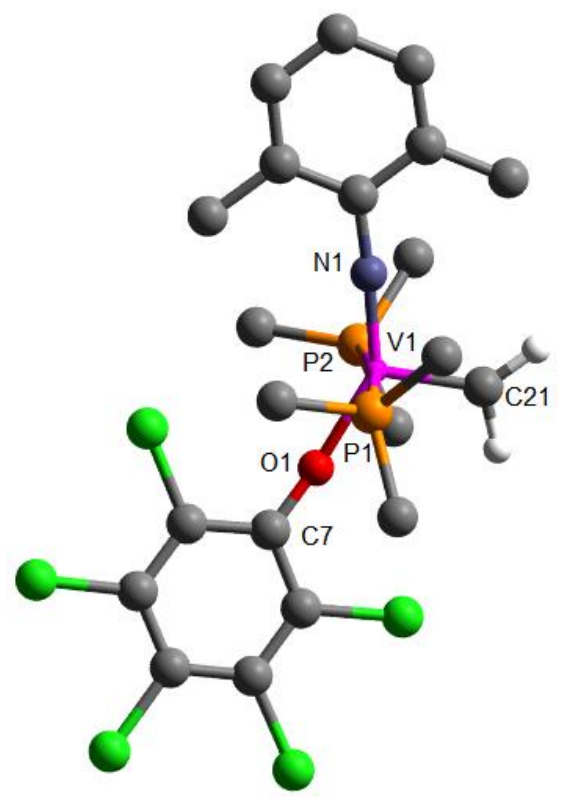

Figure S30. Geometry optimized structure for an isomer of $\left(\mathrm{OC}_{6} \mathrm{Cl}_{5}\right)[\mathrm{V}]\left(\mathrm{CH}_{2}\right)$ at the B3P86/6-311+G(d) level of theory with charge $=0$, multiplicity $=1$. Gibbs free energy $\mathrm{G}=-4881.216304$ Hartree at 298.15 K.

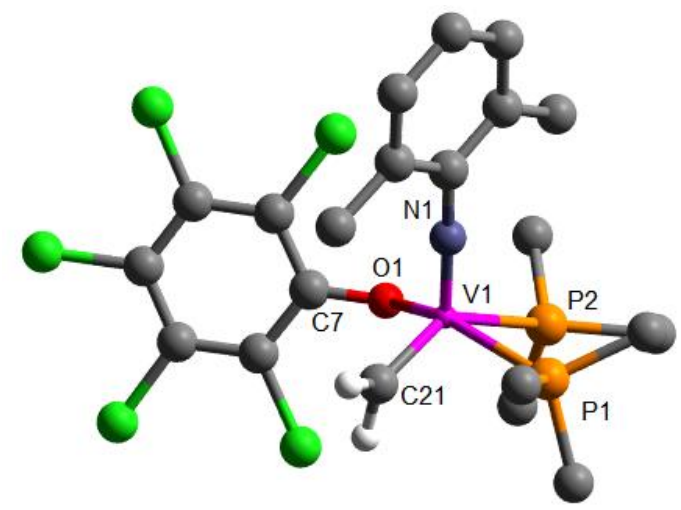

Figure S31. Geometry optimized structure for an isomer of $\left(\mathrm{OC}_{6} \mathrm{Cl}_{5}\right)[\mathrm{V}]\left(\mathrm{CH}_{2}\right)$ at the B3P86/6-311+G(d) level of theory with charge $=0$, multiplicity $=1$. Gibbs free energy $\mathrm{G}=-4881.18938$ Hartree at $298.15 \mathrm{~K}$. 

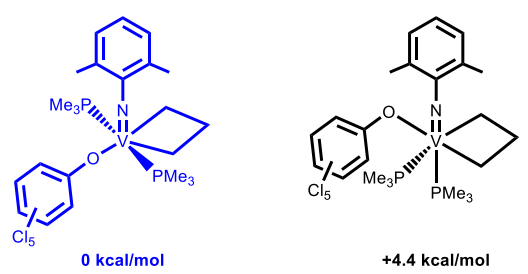

Chart S2. Calculated relative free energies of the possible isomers of $\left(\mathrm{OC}_{6} \mathrm{Cl}_{5}\right)[\mathrm{V}]\left(\mathrm{CH}_{2}-\mathrm{CH}_{2}-\mathrm{CH}_{2}\right)$ at the $\mathrm{B} 3 \mathrm{P} 86 / 6-311+\mathrm{G}(\mathrm{d})$ level of theory in $\mathrm{kcal} / \mathrm{mol}$ at $298.15 \mathrm{~K}$. The lowest energy isomer is show in blue.

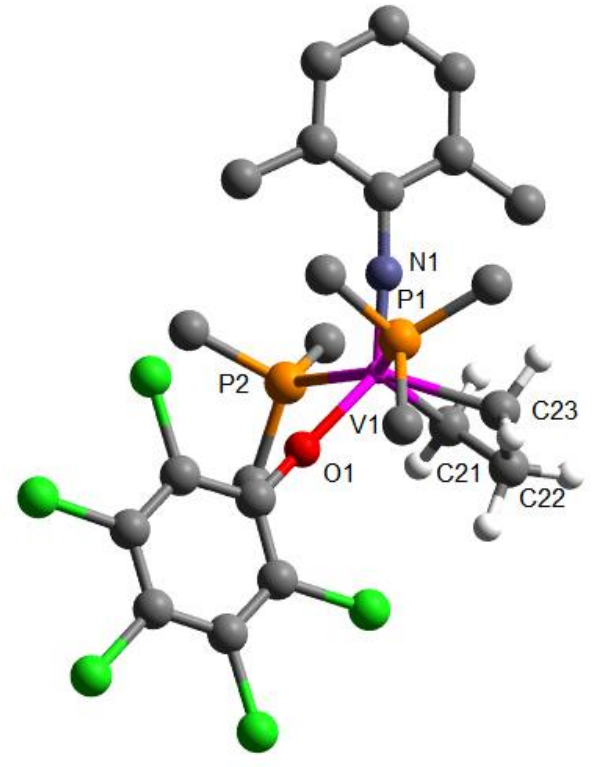

Figure S32. Geometry optimized structure for an isomer of $\left(\mathrm{OC}_{6} \mathrm{Cl}_{5}\right)[\mathrm{V}]\left(\mathrm{CH}_{2}-\mathrm{CH}_{2}-\mathrm{CH} 2\right)$ at the B3P86/6$311+\mathrm{G}(\mathrm{d})$ level of theory with charge $=0$, multiplicity $=1$. Gibbs free energy $\mathrm{G}=-4960.056516$ Hartree at $298.15 \mathrm{~K}$.

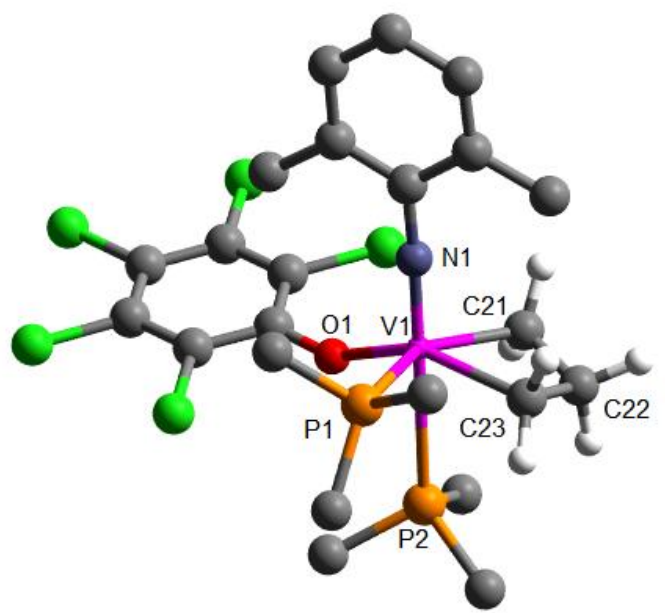

Figure S33. Geometry optimized structure for an isomer of $\left(\mathrm{OC}_{6} \mathrm{Cl}_{5}\right)[\mathrm{V}]\left(\mathrm{CH}_{2}-\mathrm{CH} 2-\mathrm{CH} 2\right)$ at the B3P86/6$311+\mathrm{G}(\mathrm{d})$ level of theory with charge $=0$, multiplicity $=1$. Gibbs free energy $\mathrm{G}=-4960.049561$ Hartree at $298.15 \mathrm{~K}$. 

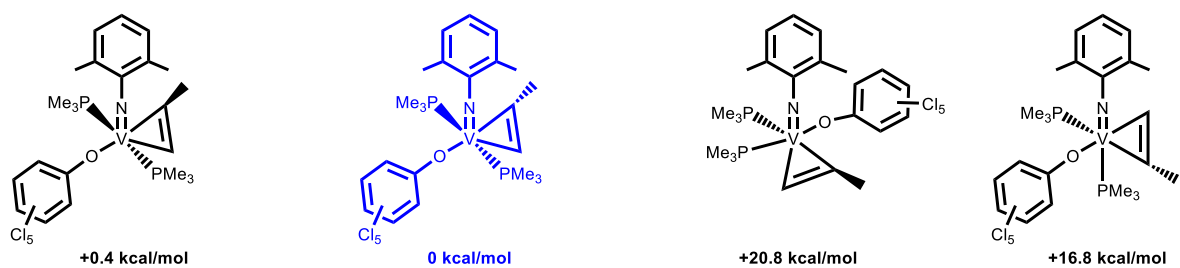

Chart S3. Calculated relative free energies of the possible isomers of $\left(\mathrm{OC}_{6} \mathrm{Cl}_{5}\right)[\mathrm{V}]\left(\mathrm{CH}_{2}-\mathrm{CH}-\mathrm{CH}_{3}\right)$ at the $\mathrm{B} 3 \mathrm{P} 86 / 6-311+\mathrm{G}(\mathrm{d})$ level of theory in $\mathrm{kcal} / \mathrm{mol}$ at $298.15 \mathrm{~K}$. The lowest energy isomer is show in blue.

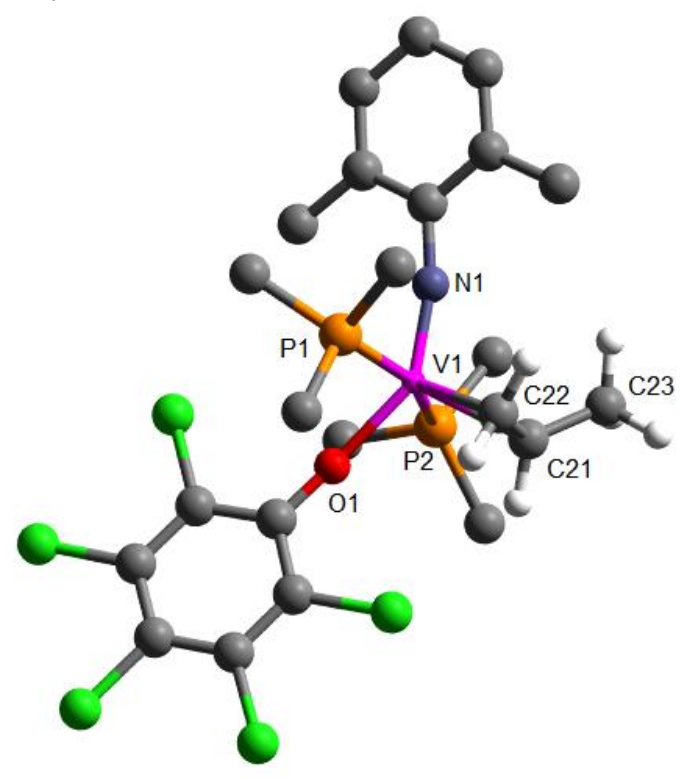

Figure S34. Geometry optimized structure for an isomer of $\left(\mathrm{OC}_{6} \mathrm{Cl}_{5}\right)[\mathrm{V}]\left(\mathrm{CH}_{2}-\mathrm{CH}-\mathrm{CH}_{3}\right)$ at the B3P86/6$311+\mathrm{G}(\mathrm{d})$ level of theory with charge $=0$, multiplicity $=1$. Gibbs free energy $\mathrm{G}=-4960.109547$ Hartree at $298.15 \mathrm{~K}$. 


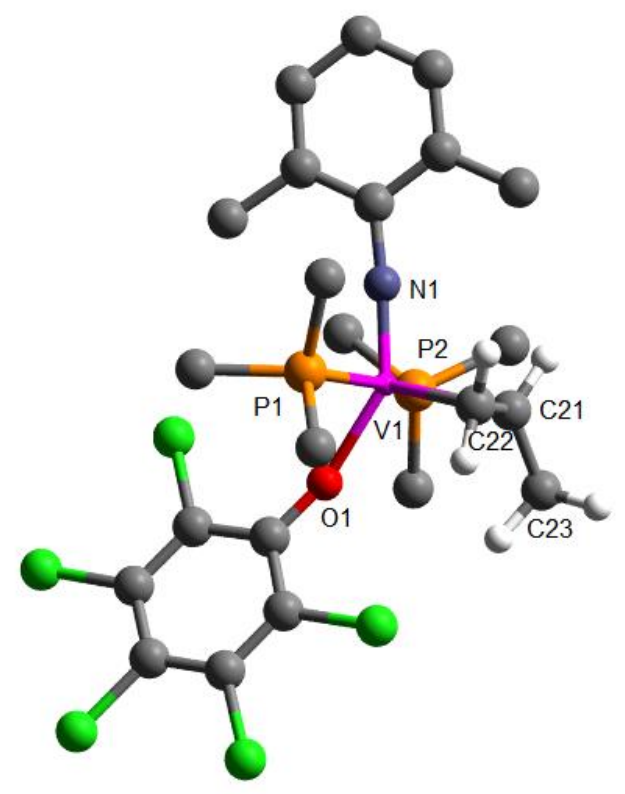

Figure S35. Geometry optimized structure for an isomer of $\left(\mathrm{OC}_{6} \mathrm{Cl}_{5}\right)[\mathrm{V}]\left(\mathrm{CH}_{2}-\mathrm{CH}-\mathrm{CH}_{3}\right)$ at the B3P86/6$311+\mathrm{G}(\mathrm{d})$ level of theory with charge $=0$, multiplicity $=1$. Gibbs free energy $\mathrm{G}=-4960.110226$ Hartree at $298.15 \mathrm{~K}$.

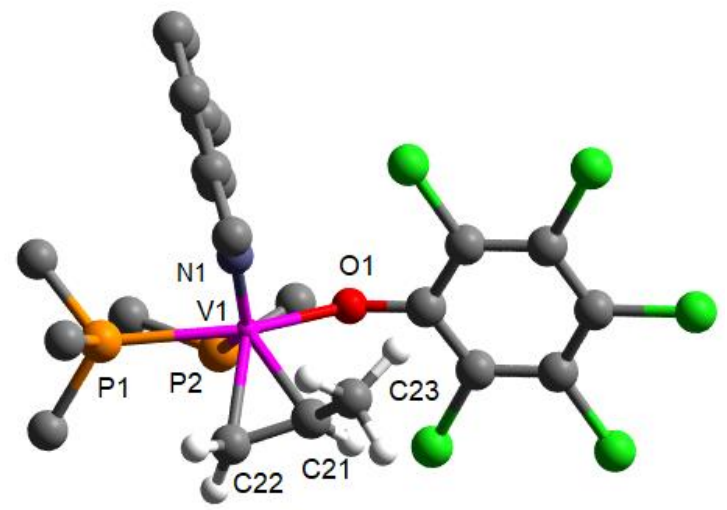

Figure S36. Geometry optimized structure for an isomer of $\left(\mathrm{OC}_{6} \mathrm{Cl}_{5}\right)[\mathrm{V}]\left(\mathrm{CH}_{2}-\mathrm{CH}_{-} \mathrm{CH}_{3}\right)$ at the B3P86/6$311+\mathrm{G}(\mathrm{d})$ level of theory with charge $=0$, multiplicity $=1$. Gibbs free energy $\mathrm{G}=-4960.07701$ Hartree at $298.15 \mathrm{~K}$. 


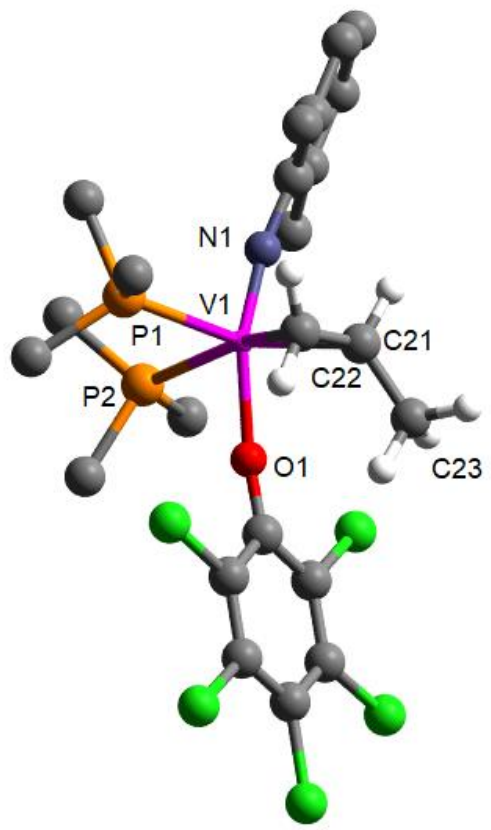

Figure S37. Geometry optimized structure for an isomer of $\left(\mathrm{OC}_{6} \mathrm{Cl}_{5}\right)[\mathrm{V}]\left(\mathrm{CH}_{2}-\mathrm{CH}-\mathrm{CH}_{3}\right)$ at the B3P86/6$311+\mathrm{G}(\mathrm{d})$ level of theory with charge $=0$, multiplicity $=1$. Gibbs free energy $\mathrm{G}=-4960.083471$ Hartree at $298.15 \mathrm{~K}$. 


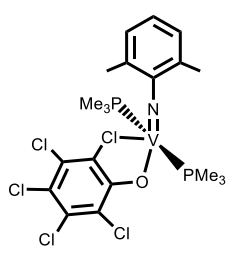

singlet

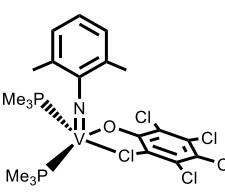

$9.6 \mathrm{kcal} / \mathrm{mol}$

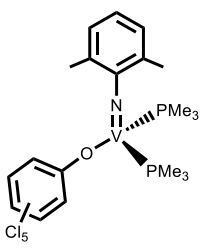

singlet<smiles>CCC(CC)N(CC)c1ccccc1C</smiles>

triplet

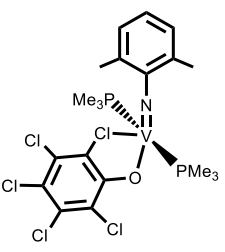

triplet
$+1.1 \mathrm{kcal} / \mathrm{mol}$

Chart S4. Calculated relative free energies of the possible isomers of $\left(\mathrm{OC}_{6} \mathrm{Cl}_{5}\right)[\mathrm{V}](\mathbf{8})$ at the B3P86/6$311+\mathrm{G}(\mathrm{d})$ level of theory in $\mathrm{kcal} / \mathrm{mol}$ at $298.15 \mathrm{~K}$. The lowest energy isomer is show in blue.

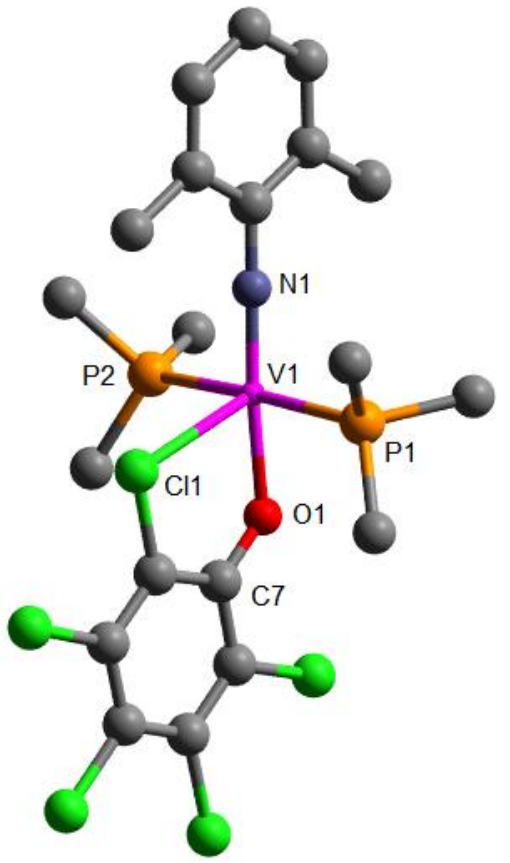

Figure S38. Geometry optimized structure for an isomer $\left(\mathrm{OC}_{6} \mathrm{Cl}_{5}\right)[\mathrm{V}](\mathbf{8})$ at the $\mathrm{B} 3 \mathrm{P} 86 / 6-311+\mathrm{G}(\mathrm{d})$ level of theory with charge $=0$, multiplicity $=1$. Gibbs free energy $\mathrm{G}=-4841.781666$ Hartree at 298.15 K.

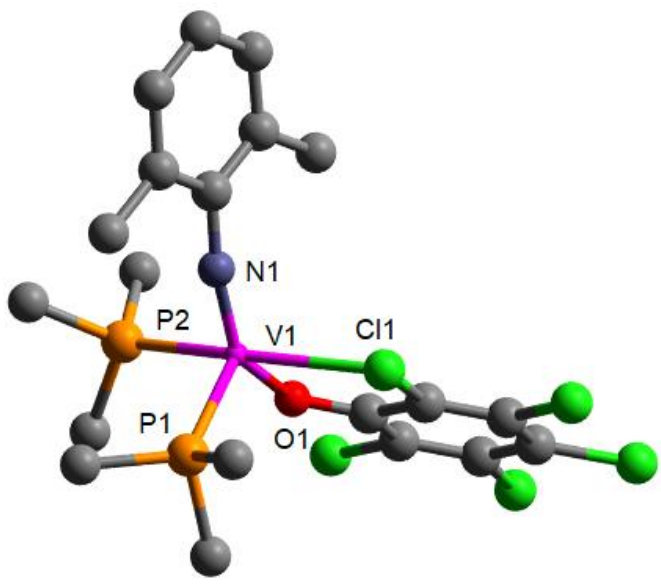

Figure S39. Geometry optimized structure for an isomer $\left(\mathrm{OC}_{6} \mathrm{Cl}_{5}\right)[\mathrm{V}](\mathbf{8})$ at the $\mathrm{B} 3 \mathrm{P} 86 / 6-311+\mathrm{G}(\mathrm{d})$ level of theory with charge $=0$, multiplicity $=1$. Gibbs free energy $G=-4841.795813$ Hartree at 298.15 K. 


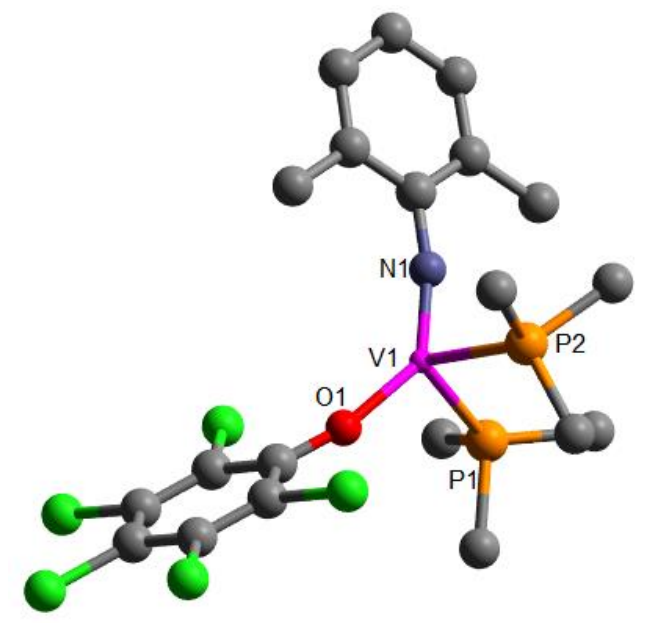

Figure S40. Geometry optimized structure for an isomer $\left(\mathrm{OC}_{6} \mathrm{Cl}_{5}\right)[\mathrm{V}](\mathbf{8})$ at the B3P86/6-311+G(d) level of theory with charge $=0$, multiplicity $=1$. Gibbs free energy $\mathrm{G}=-4841.795813$ Hartree at 298.15 K.

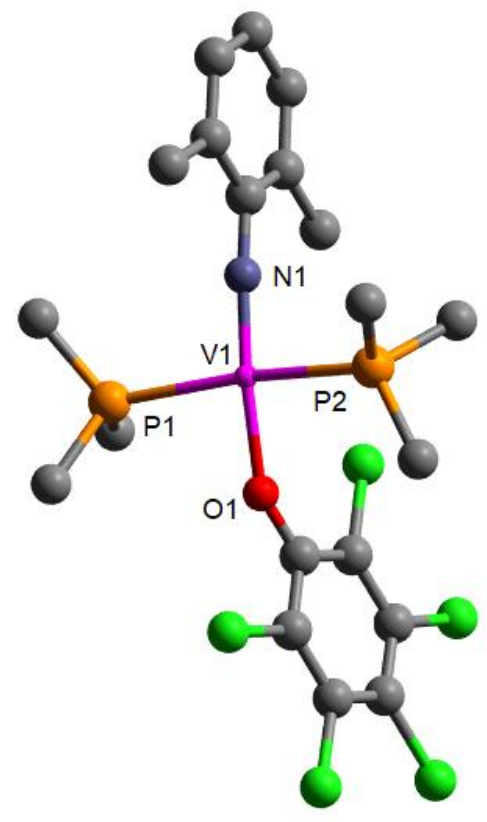

Figure S41. Geometry optimized structure for an isomer $\left(\mathrm{OC}_{6} \mathrm{Cl}_{5}\right)[\mathrm{V}](\mathbf{8})$ at the B3P86/6-311+G(d) level of theory with charge $=0$, multiplicity $=3$. Gibbs free energy $\mathrm{G}=-4841.811146$ Hartree at $298.15 \mathrm{~K}$. 


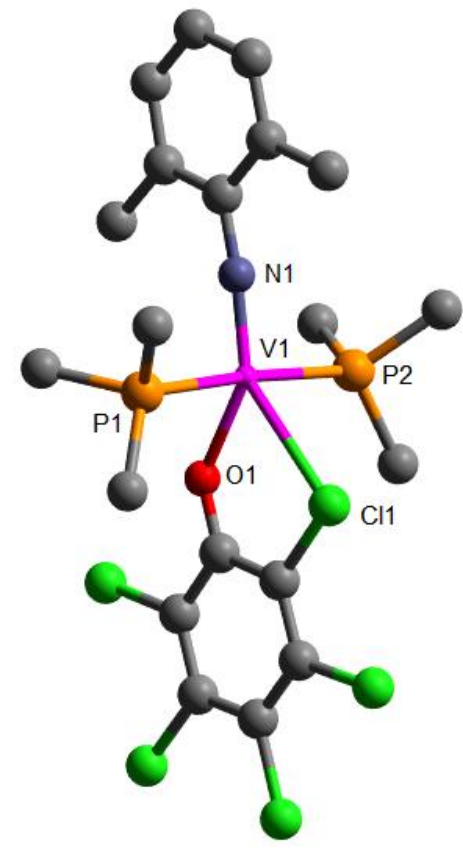

Figure S42. Geometry optimized structure for an isomer $\left(\mathrm{OC}_{6} \mathrm{Cl}_{5}\right)[\mathrm{V}](\mathbf{8})$ at the B3P86/6-311+G(d) level of theory with charge $=0$, multiplicity $=3$. Gibbs free energy $G=-4841.795813$ Hartree at 298.15 K. 


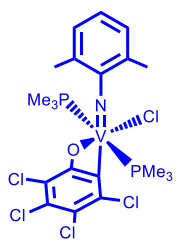

$0 \mathrm{kcal} / \mathrm{mol}$

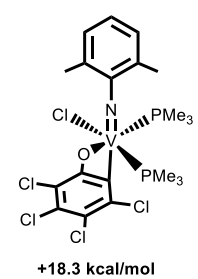

Chart S5. Calculated relative free energies of the possible isomers of $\left(\mathrm{OC}_{6} \mathrm{Cl}_{4}\right)[\mathrm{V}](\mathrm{Cl})(\mathbf{1 2})$ at the B3P86/6$311+\mathrm{G}(\mathrm{d})$ level of theory in $\mathrm{kcal} / \mathrm{mol}$ at $298.15 \mathrm{~K}$. The lowest energy isomer is show in blue.

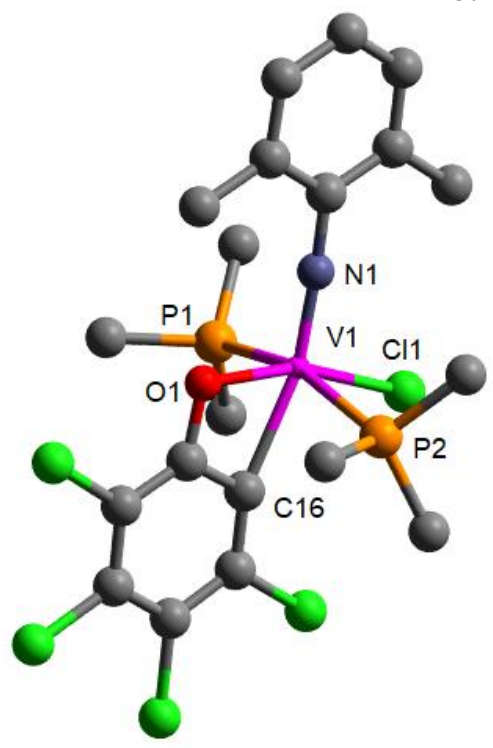

Figure S43. Geometry optimized structure for an isomer of $\left(\mathrm{OC}_{6} \mathrm{Cl}_{4}\right)[\mathrm{V}](\mathrm{Cl})(\mathbf{1 2})$ at the B3P86/6-311+G(d) level of theory with charge $=0$, multiplicity $=1$. Gibbs free energy $\mathrm{G}=-4841.835043$ Hartree at $298.15 \mathrm{~K}$.

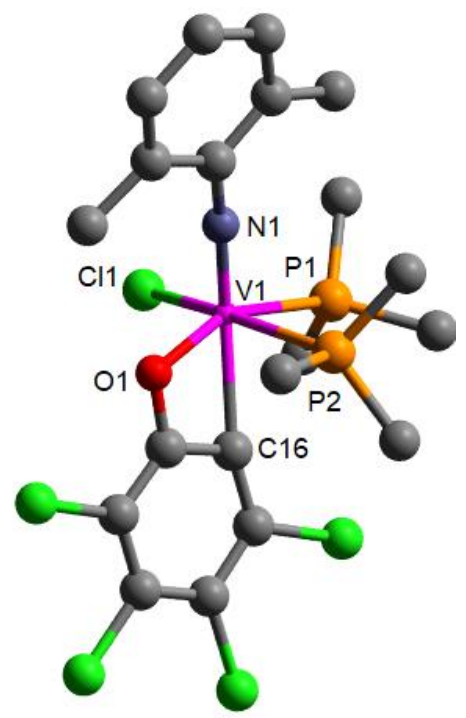

Figure S44. Geometry optimized structure for an isomer of $\left(\mathrm{OC}_{6} \mathrm{Cl}_{4}\right)[\mathrm{V}](\mathrm{Cl})(\mathbf{1 2})$ at the $\mathrm{B} 3 \mathrm{P} 86 / 6-311+\mathrm{G}(\mathrm{d})$ level of theory with charge $=0$, multiplicity $=1$. Gibbs free energy $\mathrm{G}=-4841.805929$ Hartree at $298.15 \mathrm{~K}$. 


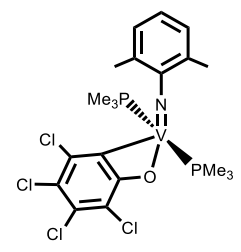

$+3.1 \mathrm{kcal} / \mathrm{mol}$

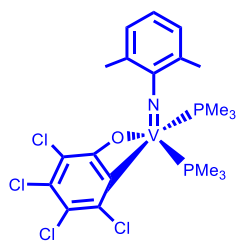

$0 \mathrm{kcal} / \mathrm{mol}$

Chart S6. Calculated relative free energies of the possible isomers of $\left(\mathrm{OC}_{6} \mathrm{Cl}_{4}\right)[\mathrm{V}](\mathbf{1 3})$ at the B3P86/6$311+\mathrm{G}(\mathrm{d})$ level of theory in $\mathrm{kcal} / \mathrm{mol}$ at $298.15 \mathrm{~K}$. The lowest energy isomer is show in blue.

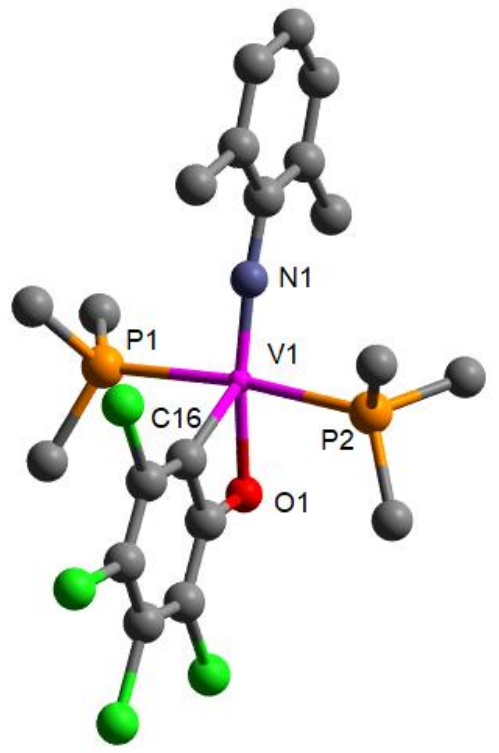

Figure S45. Geometry optimized structure for an isomer of $\left(\mathrm{OC}_{6} \mathrm{Cl}_{4}\right)[\mathrm{V}](\mathbf{1 3})$ at the $\mathrm{B} 3 \mathrm{P} 86 / 6-311+\mathrm{G}(\mathrm{d})$ level of theory with charge $=0$, multiplicity $=1$. Gibbs free energy $\mathrm{G}=-4381.240361$ Hartree at 298.15 K.

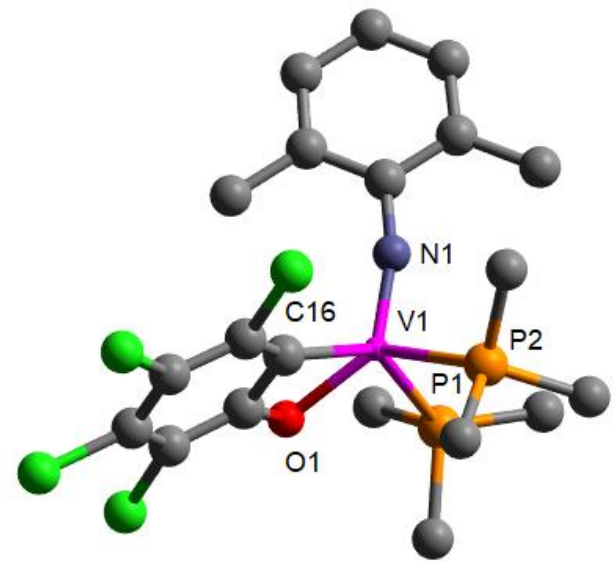

Figure S46. Geometry optimized structure for an isomer of $\left(\mathrm{OC}_{6} \mathrm{Cl}_{4}\right)[\mathrm{V}](\mathbf{1 3})$ at the B3P86/6-311+G(d) level of theory with charge $=0$, multiplicity $=1$. Gibbs free energy $\mathrm{G}=-4381.245335$ Hartree at 298.15 K. 

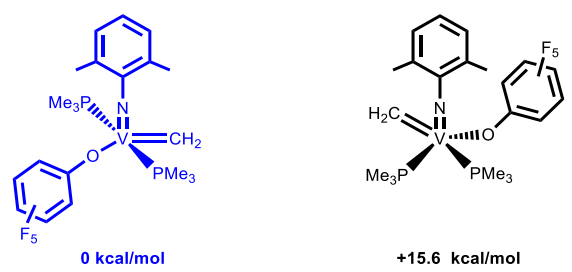

Chart S7. Calculated relative free energies of the possible isomers of $\left(\mathrm{OC}_{6} \mathrm{~F}_{5}\right)[\mathrm{V}]\left(\mathrm{CH}_{2}\right)$ at the B3P86/6$311+\mathrm{G}(\mathrm{d})$ level of theory in $\mathrm{kcal} / \mathrm{mol}$ at $298.15 \mathrm{~K}$. The lowest energy isomer is show in blue.

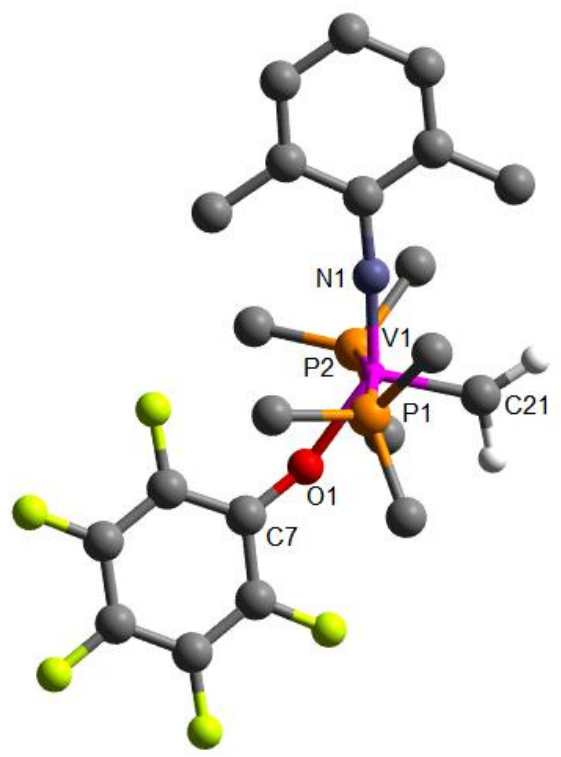

Figure S47. Calculated relative free energies of the possible isomers of $\left(\mathrm{OC}_{6} \mathrm{~F}_{5}\right)[\mathrm{V}]\left(\mathrm{CH}_{2}\right)$ at the B3P86/6$311+\mathrm{G}(\mathrm{d})$ level of theory in $\mathrm{kcal} / \mathrm{mol}$ at $298.15 \mathrm{~K}$. Gibbs free energy $\mathrm{G}=-3078.570485$ Hartree at 298.15 K.

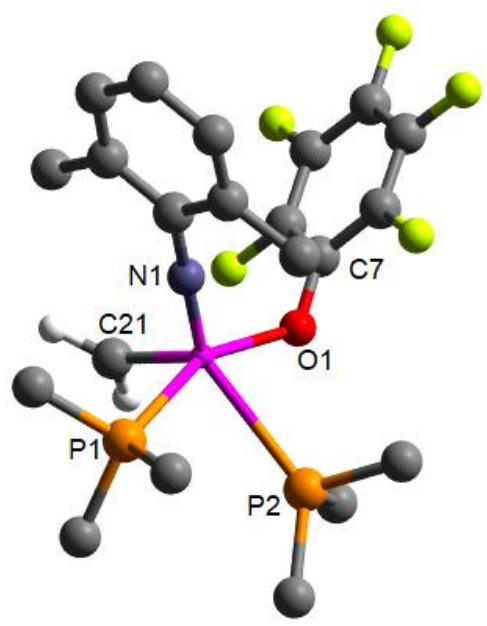

Figure S48. Geometry optimized structure for an isomer $\left(\mathrm{OC}_{6} \mathrm{~F}_{5}\right)[\mathrm{V}]\left(\mathrm{CH}_{2}\right)$ at the B3P86/6-311+G(d) level of theory with charge $=0$, multiplicity $=1$. Gibbs free energy $\mathrm{G}=-3078.545659$ Hartree at $298.15 \mathrm{~K}$. 

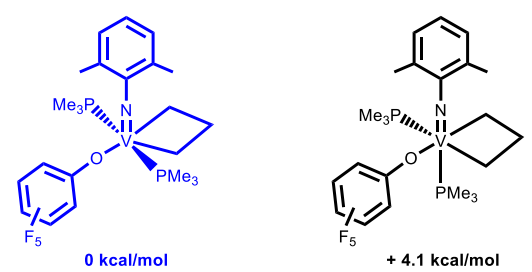

Chart S8. Calculated relative free energies of the possible isomers of $\left(\mathrm{OC}_{6} \mathrm{~F}_{5}\right)[\mathrm{V}]\left(\mathrm{CH}_{2}-\mathrm{CH}_{2}-\mathrm{CH}_{2}\right)$ at the $\mathrm{B} 3 \mathrm{P} 86 / 6-311+\mathrm{G}(\mathrm{d})$ level of theory in $\mathrm{kcal} / \mathrm{mol}$ at $298.15 \mathrm{~K}$. The lowest energy isomer is show in blue.

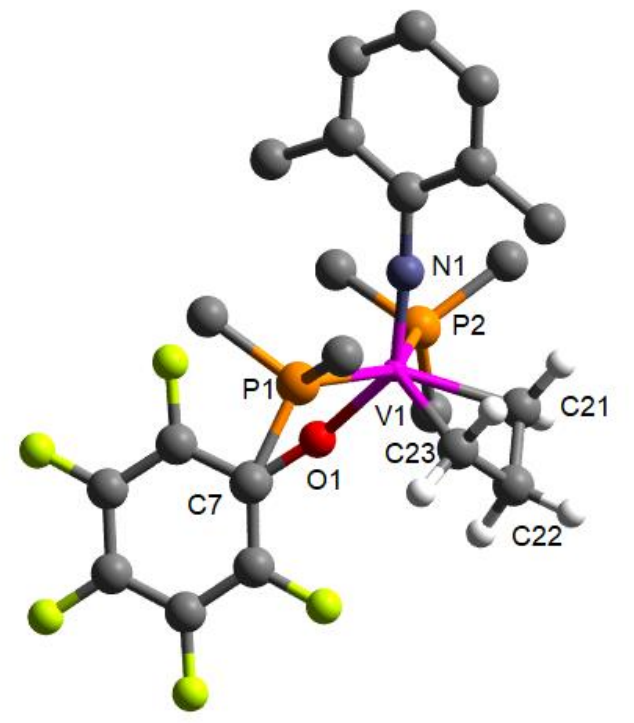

Figure S49. Geometry optimized structure for an isomer $\left(\mathrm{OC}_{6} \mathrm{~F}_{5}\right)[\mathrm{V}]\left(\mathrm{CH}_{2}-\mathrm{CH}_{2}-\mathrm{CH}_{2}\right)$ at the B3P86/6$311+\mathrm{G}(\mathrm{d})$ level of theory with charge $=0$, multiplicity $=1$. Gibbs free energy $\mathrm{G}=-3157.412346$ Hartree at $298.15 \mathrm{~K}$.

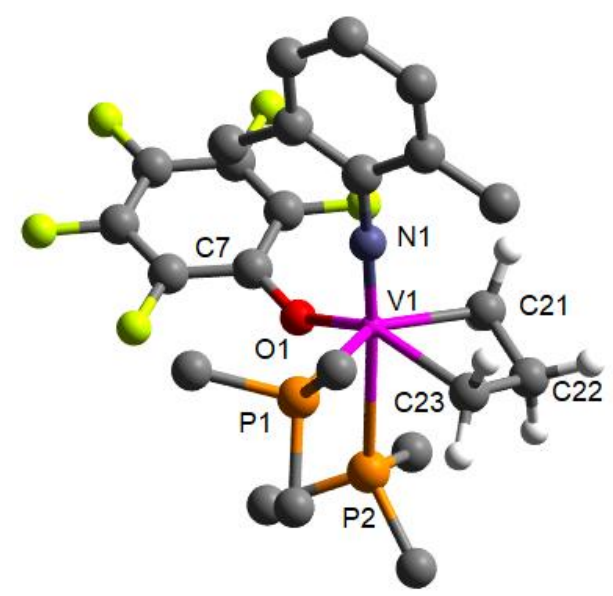

Figure S50. Geometry optimized structure for an isomer $\left(\mathrm{OC}_{6} \mathrm{~F}_{5}\right)[\mathrm{V}]\left(\mathrm{CH}_{2}-\mathrm{CH}_{2}-\mathrm{CH}_{2}\right)$ at the B3P86/6$311+\mathrm{G}(\mathrm{d})$ level of theory with charge $=0$, multiplicity $=1$. Gibbs free energy $\mathrm{G}=-3157.405807$ Hartree at $298.15 \mathrm{~K}$. 

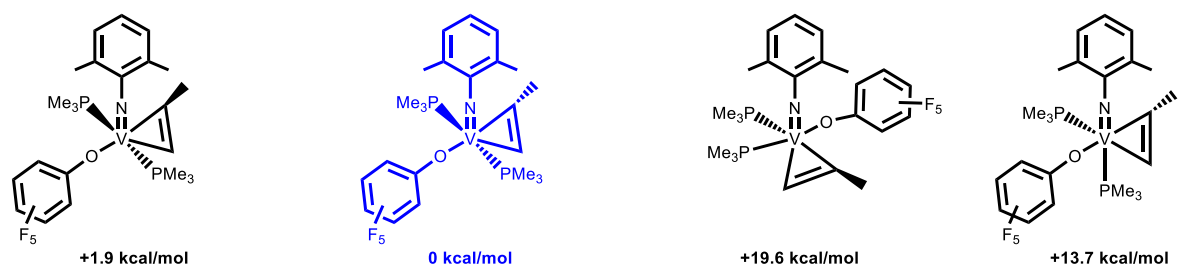

Chart S9. Calculated relative free energies of the possible isomers of $\left(\mathrm{OC}_{6} \mathrm{~F}_{5}\right)[\mathrm{V}]\left(\mathrm{CH}_{2}-\mathrm{CH}-\mathrm{CH}_{3}\right)$ at the $\mathrm{B} 3 \mathrm{P} 86 / 6-311+\mathrm{G}(\mathrm{d})$ level of theory in $\mathrm{kcal} / \mathrm{mol}$ at $298.15 \mathrm{~K}$. The lowest energy isomer is show in blue.

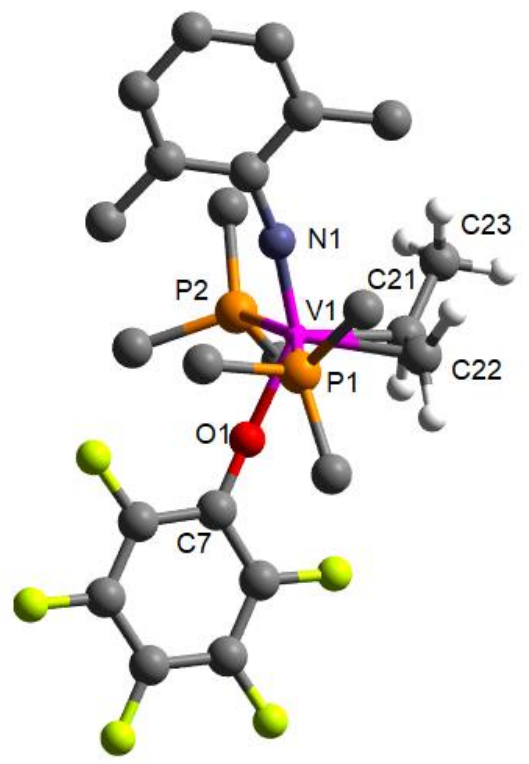

Figure S51. Geometry optimized structure for an isomer $\left(\mathrm{OC}_{6} \mathrm{~F}_{5}\right)[\mathrm{V}]\left(\mathrm{CH}_{2}-\mathrm{CH}_{-} \mathrm{CH}_{3}\right)$ at the B3P86/6$311+\mathrm{G}(\mathrm{d})$ level of theory with charge $=0$, multiplicity $=1$. Gibbs free energy $\mathrm{G}=-3157.464028$ Hartree at $298.15 \mathrm{~K}$.

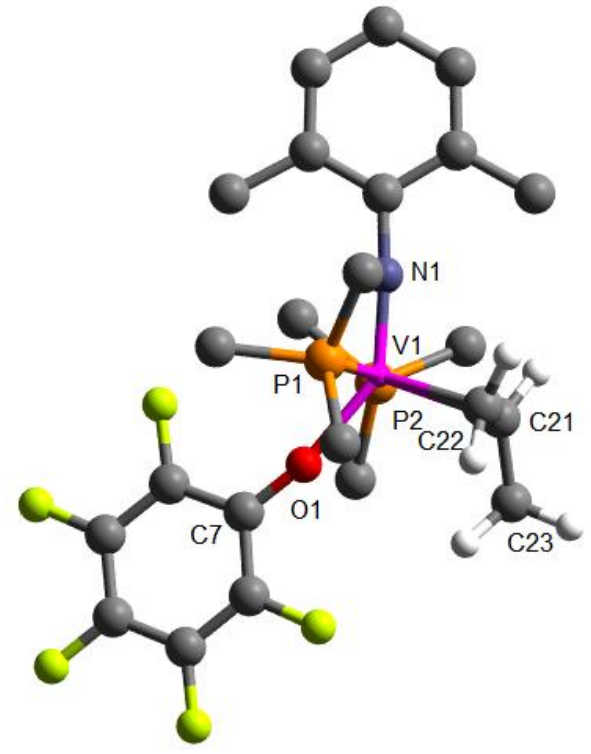

Figure S52. Geometry optimized structure for an isomer $\left(\mathrm{OC}_{6} \mathrm{~F}_{5}\right)[\mathrm{V}]\left(\mathrm{CH}_{2}-\mathrm{CH}-\mathrm{CH}_{3}\right)$ at the B3P86/6$311+\mathrm{G}(\mathrm{d})$ level of theory with charge $=0$, multiplicity $=1$. Gibbs free energy $\mathrm{G}=-3157.46647$ Hartree at $298.15 \mathrm{~K}$. 


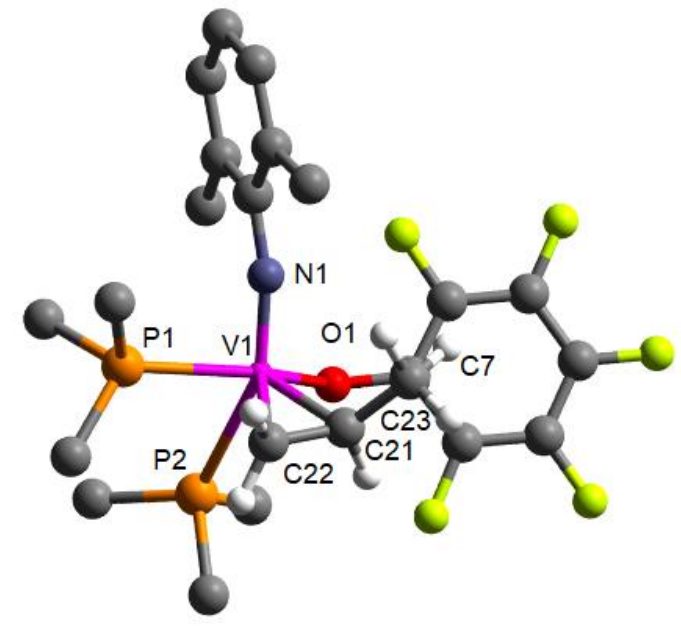

Figure S53. Geometry optimized structure for an isomer $\left(\mathrm{OC}_{6} \mathrm{~F}_{5}\right)[\mathrm{V}]\left(\mathrm{CH}_{2}-\mathrm{CH}-\mathrm{CH}_{3}\right)$ at the $\mathrm{B} 3 \mathrm{P} 86 / 6$ $311+\mathrm{G}(\mathrm{d})$ level of theory with charge $=0$, multiplicity $=1$. Gibbs free energy $\mathrm{G}=-3157.43583$ Hartree at $298.15 \mathrm{~K}$.

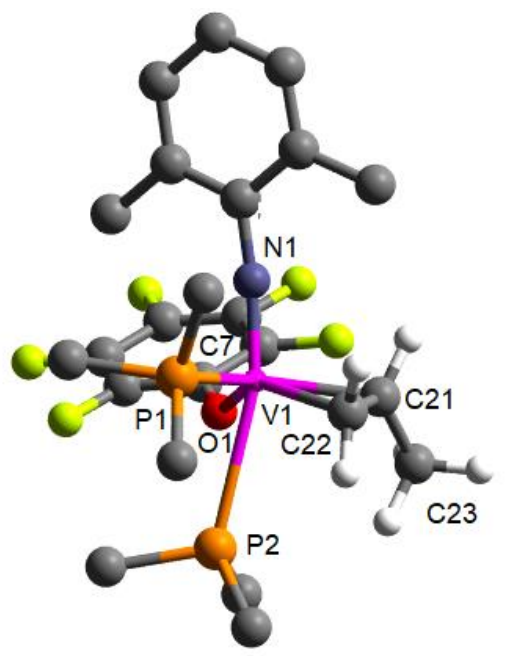

Figure S54. Geometry optimized structure for an isomer $\left(\mathrm{OC}_{6} \mathrm{~F}_{5}\right)[\mathrm{V}]\left(\mathrm{CH}_{2}-\mathrm{CH}_{-}-\mathrm{CH}_{3}\right)$ at the B3P86/6$311+\mathrm{G}(\mathrm{d})$ level of theory with charge $=0$, multiplicity $=1$. Gibbs free energy $\mathrm{G}=-3157.445308$ Hartree at $298.15 \mathrm{~K}$. 

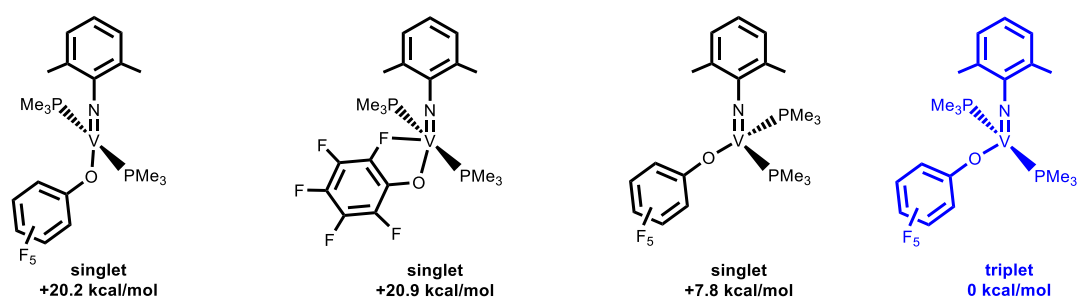

Chart S10. Calculated relative free energies of the possible isomers of $\left(\mathrm{OC}_{6} \mathrm{~F}_{5}\right)[\mathrm{V}](\mathbf{9})$ at the B3P86/6$311+\mathrm{G}(\mathrm{d})$ level of theory in $\mathrm{kcal} / \mathrm{mol}$ at $298.15 \mathrm{~K}$. The lowest energy isomer is show in blue.

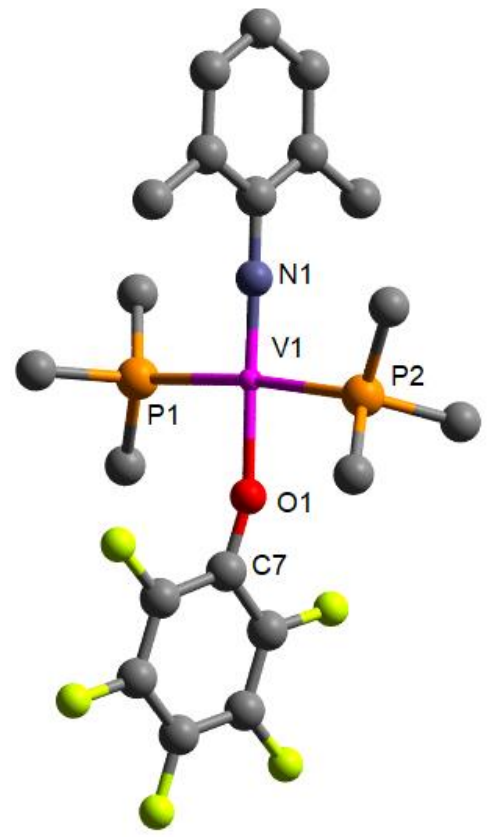

Figure S55. Geometry optimized structure for an isomer $\left(\mathrm{OC}_{6} \mathrm{~F}_{5}\right)[\mathrm{V}](\mathbf{9})$ at the B3P86/6-311+G(d) level of theory with charge $=0$, multiplicity $=1$. Gibbs free energy $\mathrm{G}=-3039.128702$ Hartree at $298.15 \mathrm{~K}$. 


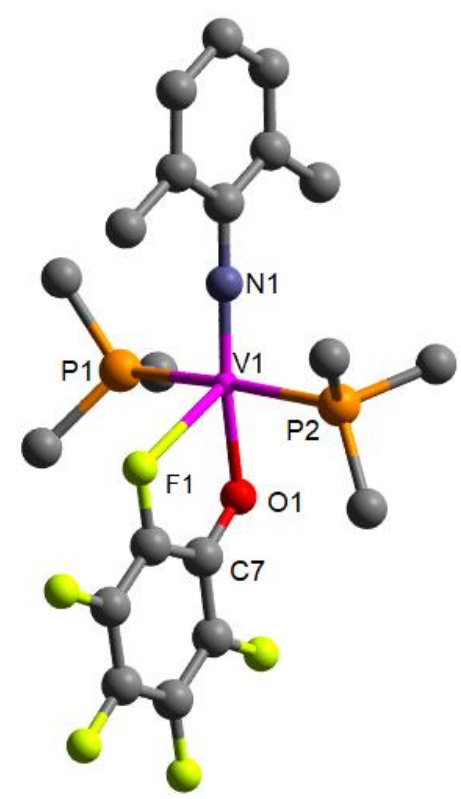

Figure S56. Geometry optimized structure for an isomer $\left(\mathrm{OC}_{6} \mathrm{~F}_{5}\right)[\mathrm{V}](\mathbf{9})$ at the B3P86/6-311+G(d) level of theory with charge $=0$, multiplicity $=1$. Gibbs free energy $\mathrm{G}=-3039.127489$ Hartree at $298.15 \mathrm{~K}$.

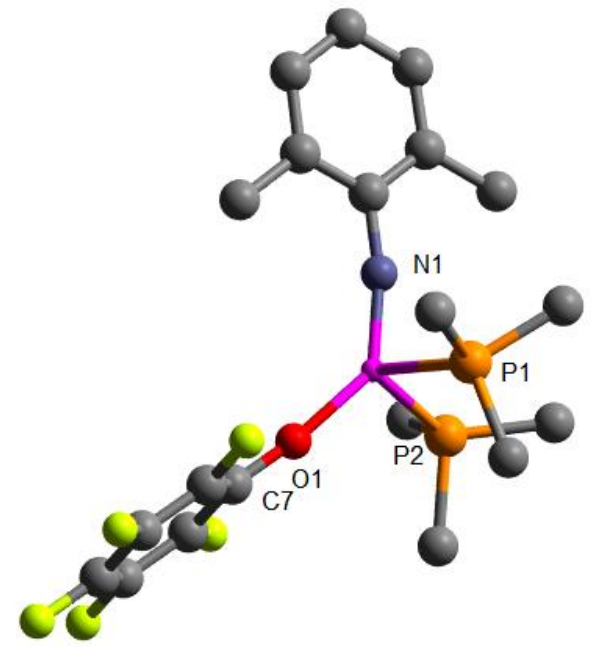

Figure S57. Geometry optimized structure for an isomer $\left(\mathrm{OC}_{6} \mathrm{~F}_{5}\right)[\mathrm{V}](\mathbf{9})$ at the B3P86/6-311+G(d) level of theory with charge $=0$, multiplicity $=1$. Gibbs free energy $\mathrm{G}=-3039.148423$ Hartree at $298.15 \mathrm{~K}$. 


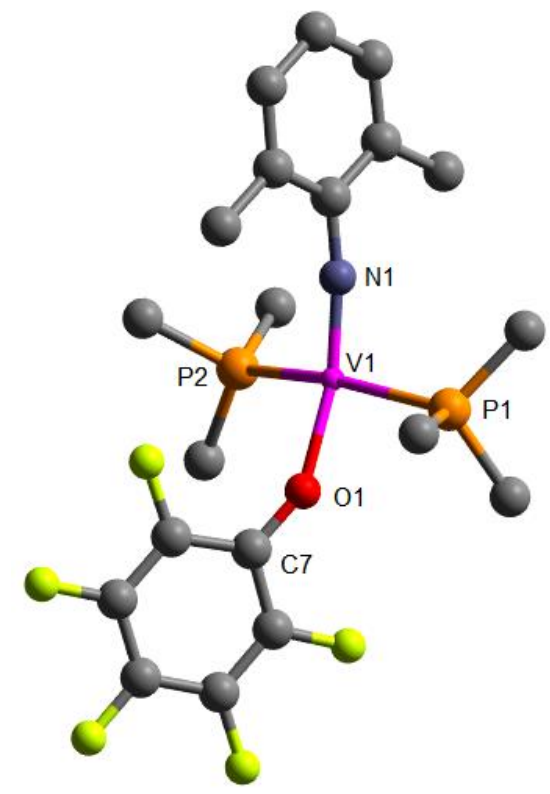

Figure S58. Geometry optimized structure for an isomer $\left(\mathrm{OC}_{6} \mathrm{~F}_{5}\right)[\mathrm{V}](\mathbf{9})$ at the B3P86/6-311+G(d) level of theory with charge $=0$, multiplicity $=3$. Gibbs free energy $\mathrm{G}=-3039.160827$ Hartree at $298.15 \mathrm{~K}$.

\section{CRYSTALOGRAPHIC INFORMATION}

\section{$\left\{\left[\mathrm{N}-2,6-\left(\mathrm{CH}_{3}\right)_{2} \mathrm{C}_{6} \mathrm{H}_{3}\right]\left(\mathrm{OC}_{6} \mathrm{Cl}_{5}\right)\left[\mathrm{P}\left(\mathrm{CH}_{3}\right)_{3}\right]_{2} \mathrm{VCl}\right\}(10)$}

Experimental information: A suitable single crystals of $\mathrm{C}_{20} \mathrm{H}_{27} \mathrm{Cl}_{6} \mathrm{NOP}_{2} \mathrm{~V}$ (UM3338) was selected and measured on a Bruker Smart Apex II CCD diffractometer. ${ }^{1}$ The crystal was kept at 150(2) K during data collection. The integral intensity were correct for absorption using SADABS software ${ }^{2}$ using multi-scan method. Resulting minimum and maximum transmission are 0.684 and 0.918 respectively. The structure was solved with the ShelXT (Sheldrick, 2015a) ${ }^{3}$ program and refined with the ShelXL (Sheldrick, 2015c) ${ }^{4}$ program and least-square minimization using ShelX software package. ${ }^{7}$ Number of restraints used $=147$.

Crystal structure determination: Crystal Data for $\mathrm{C}_{20} \mathrm{H}_{27} \mathrm{Cl}_{6} \mathrm{NOP}_{2} \mathrm{~V}(M=623.00 \mathrm{~g} / \mathrm{mol})$ : triclinic, space group P-1 (no. 2), $a=8.8697(7) \AA, b=11.1584(8) \AA, c=15.5418(12) \AA, \alpha=74.3875(10)^{\circ}, \beta=$ $78.3602(10)^{\circ}, \gamma=69.5729(10)^{\circ}, V=1378.34(18) \AA^{3}, Z=2, T=150(2) \mathrm{K}, \mu(\mathrm{MoK} \alpha)=1.072 \mathrm{~mm}^{-1}$, Dcalc $=$ $1.501 \mathrm{~g} / \mathrm{cm}^{3}, 31925$ reflections measured $\left(3.99^{\circ} \leq 2 \Theta \leq 52.998^{\circ}\right), 5671$ unique $\left(R_{\text {int }}=0.0347, \mathrm{R}_{\text {sig }}=0.0507\right)$ which were used in all calculations. The final $R_{1}$ was 0.0443 (I $\left.>2 \sigma(\mathrm{I})\right)$ and $w R_{2}$ was 0.1046 (all data).

Refinement details: The structure contains group Cl-V-PM3e disordered in 2 orientations with V just slightly shifted from each other. Therefore, it was refined with geometry restrained to be similar and atomic displacement parameters to be similar and correspond to rigid body motions.

Table S2. Sample and crystal data for $\mathbf{1 0 .}$

Identification code

Empirical formula

Formula weight

Temperature/K

Crystal system

Space group
UM3338

$\mathrm{C}_{20} \mathrm{H}_{27} \mathrm{Cl}_{6} \mathrm{NOP}_{2} \mathrm{~V}$

623.00

150(2)

triclinic

P-1 


$\begin{array}{ll}\mathrm{a} / \AA & 8.8697(7) \\ \mathrm{b} / \AA & 11.1584(8) \\ \mathrm{c} / \AA & 15.5418(12) \\ \alpha /{ }^{\circ} & 74.3875(10) \\ \beta /{ }^{\circ} & 78.3602(10) \\ \gamma^{\circ} & 69.5729(10) \\ \mathrm{Volume} / \AA^{3} & 1378.34(18) \\ \mathrm{Z} & 2 \\ \rho_{\text {calcg/cm }}{ }^{3} & 1.501 \\ \mu / \mathrm{mm}^{-1} & 1.072 \\ \mathrm{~F}(000) & 634.0 \\ \mathrm{Crystal} \text { size/mm } & \\ \text { Radiation } & 0.15 \times 0.11 \times 0.08 \\ 2 \Theta \text { range for data collection/ } & \\ \text { Index ranges } & \mathrm{MoK} \alpha(\lambda=0.71073) \\ \text { Reflections collected } & 3.99 \text { to } 52.998 \\ \text { Independent reflections } & -11 \leq \mathrm{h} \leq 11,-14 \leq \mathrm{k} \leq 14,0 \leq 1 \leq 19 \\ \text { Data/restraints/parameters } & 31925 \\ \text { Goodness-of-fit on } \mathrm{F}^{2} & 5671\left[\mathrm{R}_{\text {int }}=0.0347, \mathrm{R}_{\text {sigma }}=0.0507\right] \\ \text { Final R indexes }[\mathrm{I}>=2 \sigma(\mathrm{I})] & 5671 / 147 / 322 \\ \text { Final R indexes [all data] } & 1.000 \\ \text { Largest diff. peak/hole / e } \AA^{-3} & \mathrm{R}_{1}=0.0443, \mathrm{wR}_{2}=0.0990 \\ & \mathrm{R}_{1}=0.0620, \mathrm{wR}_{2}=0.1046 \\ & 0.58 /-0.44 \\ & \end{array}$

\section{$\left\{\left[\mathrm{N}-2,6-\left(\mathrm{CH}_{3}\right)_{2} \mathrm{C}_{6} \mathrm{H}_{3}\right] \mathrm{V}\left(\mathrm{OC}_{6} \mathrm{~F}_{5}\right)_{2}\left[\mathrm{P}\left(\mathrm{CH}_{3}\right)_{3}\right]_{2}\right\}(11)$}

Experimental information:A suitable single crystals of $\mathrm{C}_{26} \mathrm{H}_{27} \mathrm{~F}_{10} \mathrm{NO}_{2} \mathrm{P}_{2} \mathrm{~V}$ (UM3363) was selected and measured on a Bruker Smart Apex II CCD diffractometer. ${ }^{1}$ The crystal was kept at 150(2) K during data collection. The integral intensity were correct for absorption using SADABS software ${ }^{2}$ using multi-scan method. Resulting minimum and maximum transmission are 0.867 and 0.982 respectively. The structure was solved with the ShelXT (Sheldrick, 2015a) ${ }^{3}$ program and refined with the ShelXL (Sheldrick, 2015c) ${ }^{4}$ program and least-square minimization using ShelX software package. ${ }^{6}$ Number of restraints used $=0$.

Crystal structure determination: Crystal Data for $\mathrm{C}_{26} \mathrm{H}_{27} \mathrm{~F}_{10} \mathrm{NO}_{2} \mathrm{P}_{2} \mathrm{~V}(M=688.36 \mathrm{~g} / \mathrm{mol})$ : monoclinic, space group $\mathrm{P} 2 / \mathrm{n}$ (no. 13), $a=11.0107(7) \AA, b=12.6143(7) \AA, c=11.2754(7) \AA, \beta=101.4699(10)^{\circ}, V=$ 1534.79(16) $\AA^{3}, Z=2, T=150(2) \mathrm{K}, \mu(\mathrm{MoK} \alpha)=0.513 \mathrm{~mm}^{-1}$, Dcalc $=1.490 \mathrm{~g} / \mathrm{cm}^{3}, 26389$ reflections measured $\left(3.228^{\circ} \leq 2 \Theta \leq 61.998^{\circ}\right), 4903$ unique $\left(R_{\text {int }}=0.0334, \mathrm{R}_{\text {sig }}=0.0340\right)$ which were used in all calculations. The final $R_{1}$ was 0.0337 (I $>2 \sigma(\mathrm{I})$ ) and $w R_{2}$ was 0.0750 (all data).

Table S3. Sample and crystal data for 11.

Identification code

UM3363

Empirical formula

$\mathrm{C}_{26} \mathrm{H}_{27} \mathrm{~F}_{10} \mathrm{NO}_{2} \mathrm{P}_{2} \mathrm{~V}$

Formula weight

688.36

Temperature/K

150(2)

Crystal system

monoclinic 


$\begin{array}{ll}\text { Space group } & \mathrm{P} 2 / \mathrm{n} \\ \mathrm{a} / \AA & 11.0107(7) \\ \mathrm{b} / \AA & 12.6143(7) \\ \mathrm{c} / \AA & 11.2754(7) \\ \alpha^{\circ} & 90 \\ \beta /{ }^{\circ} & 101.4699(10) \\ \gamma^{\circ} & 90 \\ \text { Volume/ } \AA^{3} & 1534.79(16) \\ \mathrm{Z} & 2 \\ \rho_{\text {calcg/cm }}{ }^{3} & 1.490 \\ \mu / \mathrm{mm}^{-1} & 0.513 \\ \mathrm{~F}(000) & 698.0 \\ \mathrm{Crystal} \text { size/mm } & \\ \text { Radiation } & 0.37 \times 0.15 \times 0.035 \\ 2 \Theta \text { range for data collection } /{ }^{\circ} & \mathrm{MoK} \alpha(\lambda=0.71073) \\ \text { Index ranges } & 3.228 \text { to } 61.998 \\ \text { Reflections collected } & -15 \leq \mathrm{h} \leq 15,-18 \leq \mathrm{k} \leq 18,-16 \leq 1 \leq 16 \\ \text { Independent reflections } & 26389 \\ \text { Data/restraints/parameters } & 4903\left[\mathrm{R}_{\text {int }}=0.0334, \mathrm{R}_{\text {sigma }}=0.0340\right] \\ \text { Goodness-of-fit on } \mathrm{F}^{2} & 4903 / 0 / 246 \\ \text { Final } \mathrm{R} \text { indexes }[\mathrm{I}>=2 \sigma(\mathrm{I})] & 1.000 \\ \text { Final } \mathrm{R} \text { indexes [all data] } & \mathrm{R}_{1}=0.0337, \mathrm{wR}_{2}=0.0723 \\ \text { Largest diff. peak/hole } / \mathrm{e} \AA^{-3} & \mathrm{R}_{1}=0.0446, \mathrm{wR}_{2}=0.0750 \\ & 0.35 /-0.26 \\ & \end{array}$

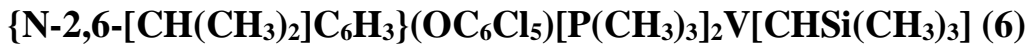

Experimental information: A suitable single crystals of $\mathrm{C}_{28} \mathrm{H}_{45} \mathrm{Cl}_{5} \mathrm{NOP}_{2} \mathrm{SiV}$ (UM3405) was selected and measured on a Bruker Smart Apex II CCD diffractometer. ${ }^{1}$ The crystal was kept at 150(2) K during data collection. The integral intensity were correct for absorption using SADABS software ${ }^{2}$ using multi-scan method. Resulting minimum and maximum transmission are 0.747 and 0.955 respectively. The structure was solved with the ShelXT (Sheldrick, 2015a) ${ }^{3}$ program and refined with the ShelXL (Sheldrick, 2015c) ${ }^{4}$ program and least-square minimisation using ShelX software package. ${ }^{4}$ Number of restraints used $=318$.

Crystal structure determination: Crystal Data for $\mathrm{C}_{28} \mathrm{H}_{45} \mathrm{Cl}_{5} \mathrm{NOP}_{2} \mathrm{SiV}(M=729.87 \mathrm{~g} / \mathrm{mol})$ : monoclinic, space group $\mathrm{P} 21 / \mathrm{n}$ (no. 14), $a=12.8516(12) \AA, b=21.463(2) \AA, c=13.6088(13) \AA, \beta=90.0045(15)^{\circ}, V=$ 3753.7(6) $\AA^{3}, Z=4, T=150(2) \mathrm{K}, \mu(\mathrm{MoK} \alpha)=0.759 \mathrm{~mm}^{-1}$, Dcalc $=1.291 \mathrm{~g} / \mathrm{cm}^{3}, 45874$ reflections measured $\left(2.992^{\circ} \leq 2 \Theta \leq 60^{\circ}\right), 10930$ unique $\left(R_{\text {int }}=0.0415, \mathrm{R}_{\text {sig }}=0.0427\right)$ which were used in all calculations. The final $R_{1}$ was 0.0461 (I $\left.>2 \sigma(\mathrm{I})\right)$ and $w R_{2}$ was 0.1032 (all data).

Refinement details: Refined as a 2-component pseudo-merohedral twin by 180 deg rotation around 001 axis yielding components ratio of $0.549(1): 0.451(1)$. $\mathrm{O}-\mathrm{C}_{6} \mathrm{Cl}_{5}$ group is disordered in 2 alternative orientations in 0.789(2):0.211(2)ratio and was refined with geometry restrained to be similar and atomic displacement parameters to correspond to rigid body motions. Coordinates of H19 atom at C19 bridging Si and $\mathrm{V}$ atoms were freely refined with Uiso constrained to be $50 \%$ larger than Ueqv of C19 atom.

Table S4. Sample and crystal data for 6. 


\begin{tabular}{|c|c|}
\hline Identification code & UM3405 \\
\hline Empirical formula & $\mathrm{C}_{28} \mathrm{H}_{45} \mathrm{Cl}_{5} \mathrm{NOP}_{2} \mathrm{SiV}$ \\
\hline Formula weight & 729.87 \\
\hline Temperature/K & $150(2)$ \\
\hline Crystal system & monoclinic \\
\hline Space group & $\mathrm{P} 2{ }_{1} / \mathrm{n}$ \\
\hline $\mathrm{a} / \AA ̊$ & $12.8516(12)$ \\
\hline $\mathrm{b} / \AA$ & $21.463(2)$ \\
\hline $\mathrm{c} / \AA$ & $13.6088(13)$ \\
\hline$\alpha /^{\circ}$ & 90 \\
\hline$\beta /{ }^{\circ}$ & $90.0045(15)$ \\
\hline$\gamma /{ }^{\circ}$ & 90 \\
\hline Volume $/ \AA^{3}$ & $3753.7(6)$ \\
\hline $\mathrm{Z}$ & 4 \\
\hline$\rho_{\text {calc }} \mathrm{g} / \mathrm{cm}^{3}$ & 1.291 \\
\hline$\mu / \mathrm{mm}^{-1}$ & 0.759 \\
\hline $\mathrm{F}(000)$ & 1520.0 \\
\hline Crystal size $/ \mathrm{mm}^{3}$ & $0.33 \times 0.28 \times 0.06$ \\
\hline Radiation & $\operatorname{MoK} \alpha(\lambda=0.71073)$ \\
\hline $2 \Theta$ range for data collection ${ }^{\circ}$ & 2.992 to 60 \\
\hline Index ranges & $-18 \leq \mathrm{h} \leq 18,-30 \leq \mathrm{k} \leq 30,-19 \leq 1 \leq 19$ \\
\hline Reflections collected & 45874 \\
\hline Independent reflections & $10930\left[R_{\text {int }}=0.0415, R_{\text {sigma }}=0.0427\right]$ \\
\hline Data/restraints/parameters & $10930 / 318 / 478$ \\
\hline Goodness-of-fit on $\mathrm{F}^{2}$ & 1.000 \\
\hline Final $R$ indexes $[\mathrm{I}>=2 \sigma(\mathrm{I})]$ & $\mathrm{R}_{1}=0.0461, \mathrm{w} \mathrm{R}_{2}=0.0986$ \\
\hline Final $\mathrm{R}$ indexes [all data] & $\mathrm{R}_{1}=0.0577, \mathrm{wR}_{2}=0.1032$ \\
\hline Largest diff. peak/hole / e $\AA^{-3}$ & $0.83 /-0.39$ \\
\hline
\end{tabular}

\section{$\left\{\mathrm{N}-2,6-\left[\mathrm{CH}\left(\mathrm{CH}_{3}\right)_{2}\right] \mathrm{C}_{6} \mathrm{H}_{3}\right\}\left(\mathrm{OC}_{6} \mathrm{~F}_{5}\right)\left[\mathrm{P}\left(\mathrm{CH}_{3}\right)_{3}\right]_{2} \mathrm{~V}\left[\mathrm{CHSi}\left(\mathrm{CH}_{3}\right)_{3}\right](7)$}

Experimental: A suitable single crystals of $\mathrm{C}_{28} \mathrm{H}_{45} \mathrm{~F}_{5} \mathrm{NOP}_{2} \mathrm{SiV}$ (UM3406) was selected and measured on a Bruker Smart Apex II CCD diffractometer. ${ }^{1}$ The crystal was kept at 150(2) K during data collection. The integral intensity were correct for absorption using SADABS software ${ }^{2}$ using multi-scan method. Resulting minimum and maximum transmission are 0.740 and 0.959 respectively. The structure was solved with the ShelXT (Sheldrick, 2015a) ${ }^{3}$ program and refined with the ShelXL (Sheldrick, 2015c) ${ }^{4}$ program and leastsquare minimisation using ShelX software package. ${ }^{4}$ Number of restraints used $=0$.

Crystal structure determination: Crystal Data for $\mathrm{C}_{28} \mathrm{H}_{45} \mathrm{~F}_{5} \mathrm{NOP}_{2} \mathrm{SiV}(M=647.62 \mathrm{~g} / \mathrm{mol})$ : monoclinic, space group $\mathrm{P} 21 / \mathrm{c}$ (no. 14), $a=9.571(2) \AA, b=38.361(8) \AA, c=9.326(2) \AA, \beta=93.175(5)^{\circ}, V=3418.5(13) \AA^{3}$, $Z=4, T=150(2) \mathrm{K}, \mu(\mathrm{MoK} \alpha)=0.467 \mathrm{~mm}^{-1}$, Dcalc $=1.258 \mathrm{~g} / \mathrm{cm}^{3}, 14119$ reflections measured $\left(4.248^{\circ} \leq\right.$ $\left.2 \Theta \leq 49.998^{\circ}\right), 6009$ unique $\left(R_{\text {int }}=0.0546, \mathrm{R}_{\text {sig }}=0.0859\right)$ which were used in all calculations. The final $R_{1}$ was $0.0770(\mathrm{I}>2 \sigma(\mathrm{I}))$ and $w R_{2}$ was 0.1794 (all data). 
Refinement details: During the data collection the crystal shows signs of slow decomposition or phase transition that was corrected for along with absorption correction.

Table S5. Sample and crystal data for 7.

\begin{tabular}{|c|c|}
\hline Identification code & UM3406 \\
\hline Empirical formula & $\mathrm{C}_{28} \mathrm{H}_{45} \mathrm{~F}_{5} \mathrm{NOP}_{2} \mathrm{SiV}$ \\
\hline Formula weight & 647.62 \\
\hline Temperature/K & $150(2)$ \\
\hline Crystal system & monoclinic \\
\hline Space group & $\mathrm{P} 2{ }_{1} / \mathrm{c}$ \\
\hline $\mathrm{a} / \AA ̊ \AA$ & $9.571(2)$ \\
\hline $\mathrm{b} / \AA$ & $38.361(8)$ \\
\hline $\mathrm{c} / \AA ̊ \AA$ & $9.326(2)$ \\
\hline$\alpha /^{\circ}$ & 90 \\
\hline$\beta /{ }^{\circ}$ & $93.175(5)$ \\
\hline$\gamma /{ }^{\circ}$ & 90 \\
\hline Volume $/ \AA^{3}$ & $3418.5(13)$ \\
\hline $\mathrm{Z}$ & 4 \\
\hline$\rho_{\text {calc }} \mathrm{g} / \mathrm{cm}^{3}$ & 1.258 \\
\hline$\mu / \mathrm{mm}^{-1}$ & 0.467 \\
\hline $\mathrm{F}(000)$ & 1360.0 \\
\hline Crystal size $/ \mathrm{mm}^{3}$ & $0.29 \times 0.19 \times 0.09$ \\
\hline Radiation & $\operatorname{MoK} \alpha(\lambda=0.71073)$ \\
\hline $2 \Theta$ range for data collection ${ }^{\circ}$ & 4.248 to 49.998 \\
\hline Index ranges & $-11 \leq \mathrm{h} \leq 11,-45 \leq \mathrm{k} \leq 39,-6 \leq 1 \leq 11$ \\
\hline Reflections collected & 14119 \\
\hline Independent reflections & $6009\left[R_{\text {int }}=0.0546, R_{\text {sigma }}=0.0859\right]$ \\
\hline Data/restraints/parameters & $6009 / 0 / 365$ \\
\hline Goodness-of-fit on $\mathrm{F}^{2}$ & 1.057 \\
\hline Final $\mathrm{R}$ indexes $[\mathrm{I}>=2 \sigma(\mathrm{I})]$ & $\mathrm{R}_{1}=0.0770, \mathrm{wR}_{2}=0.1690$ \\
\hline Final $R$ indexes [all data] & $\mathrm{R}_{1}=0.1056, \mathrm{wR}_{2}=0.1794$ \\
\hline Largest diff. peak/hole / e $\AA^{-3}$ & $1.38 /-0.52$ \\
\hline
\end{tabular}

\section{REFERENCES}

1. Bruker (2010). Apex2. Bruker AXS Inc., Madison, Wisconsin, USA.

2. Krause, L., Herbst-Irmer, R., Sheldrick, G.M., Stalke, D. J. Appl. Cryst. 2015,48, 3-10.

3. Sheldrick, G. M.ActaCryst. 2015, A17, 3-8.

4. Sheldrick, G. M. ActaCryst. 2015, C17, 3-8. 